XX1.--Experiments to show how Failure under Stress occurs in Timber, its Cause, and Comparative Values of the Maximum Stresses induced when Timber is fractured in Various Ways. By Angus R. Fulton, B.Sc., A.M.Inst.C.E., Engineering Department, University College, Dundee. Communicated by Professor W. Peddre. (With Eight Plates and Five Text Illustrations.)

(MS. received July 10, 1911. Read November 13, 1911. Issued separately August 30, 1912.)

\title{
INTRODUCTION.
}

The object of this investigation was not to obtain fresh data on the average strength of timber when subjected to destructive stresses. This has been done in great detail by Bauschinger, LANZA, JoHnson, and others, and is still being carried on, in America, on a large scale under the Bureau of Forestry. The intention was rather $(a)$ to find the effect of the medullary rays when timber was stressed in compression, tension, shear, or by cross-bending; and (b) to endeavour to connect up in a satisfactory way the maximum stresses induced in cross-breaking with those obtained by direct compression, tension, or shear. For this purpose, then, it was not necessary that the number of experiments should be excessive, but it was essential that the results obtained should be comparable one with another. To obtain this, a single tree of each variety of wood to be tested was procured, the test pieces were sawn out of the best part of the trunk, carefully stacked, and allowed to season for at least twelve months.

As the timber was stored in a perfectly dry, well-ventilated room, as the specific gravity values were practically constant at the time of carrying out the tests, and as the tests were mainly relative ones, it was not thought necessary to determine the actual moisture conditions.

Four varieties of wood were chosen--Oak, Pitch Pine, Ash, and Box. The two former are representative of the class in which the medullary rays are very pronounced, and the two latter, of those in which they are much less marked.

The Oak specimens were cut from a trunk 21 inches diameter, the Ash 24 inches diameter, and the Box 8 inches diameter; and the place of growth was known only for the Oak, which was Scone Palace grounds.

The test pieces were rectangular in section, with one pair of parallel faces as far as possible tangential to the annual rings, and the other pair consequently parallel to the medullary rays, the length being measured along the axis of the tree. The dimensions of the cross-section were approximately in the ratio of 2

TRANS. ROY. SOC. EDIN., VOL. XLVIII., PART II. (NO. 21). 
to 1 , the deep sides being in a number of cases parallel to the rings, and in an equal number of cases parallel to the medullary rays. Any advantage peculiar to the position of the rings or rays in the test piece would thus be accentuated.

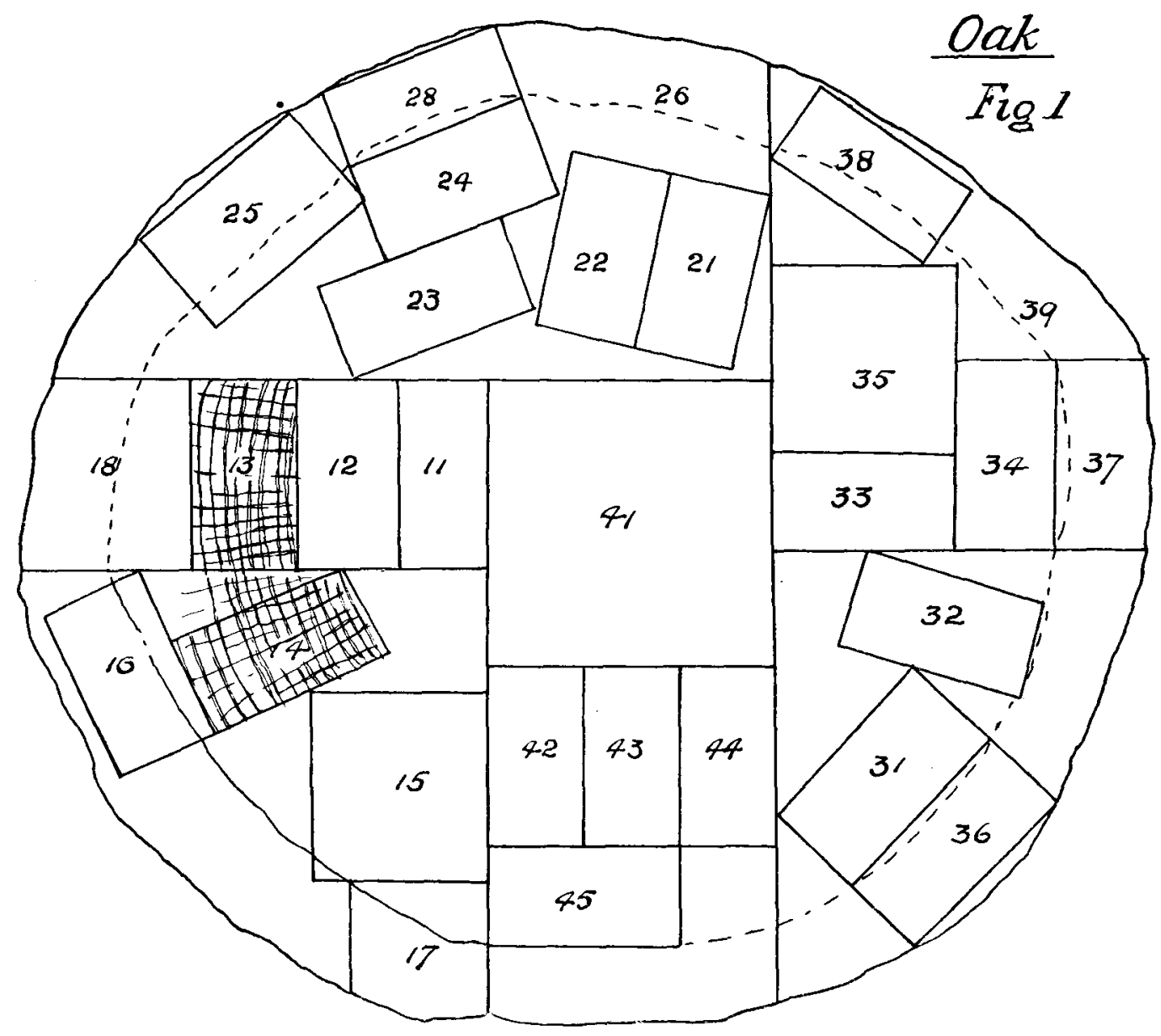

Fig. 1 is a drawing of the cross-section of the Oak tree used, and shows the manner in which the specimens were cut from that section; it is also an example of the method followed in the case of the other woods.

\section{DEFinition of Stresses.}

The following definitions of stresses have been adopted throughout this paper :-

(a) A longitudinal stress is a stress acting parallel to the axis of the tree.

(b) A radial stress is a stress acting as nearly as may be parallel to the medullary rays, and therefore perpendicular to the annual rings. 
(c) A tangential stress is a stress acting parallel to the annual rings, and therefore perpendicular to the medullary rays.

Our direct forces will, as far as possible, be such as produce stresses in these directions.

(d) In the case of a beam with its axis horizontal and the medullary rays in its cross-section set vertically, we have stresses induced in a longitudinal direction as in $(a)$, and a horizontal shear stress which is along the plane of the annual rings. This latter stress will be called a tangential shear stress.

(e) Similarly, if the beam is laid with the medullary rays horizontal, the horizontal shear stress is along the plane of the medullary rays, and will be called a radial shear stress.

\section{Longitudinal Compressive Stress.}

(a) Characteristic Failure of Timber.

If we consider a test piece of timber subjected to a longitudinal compressive stress sufficient to cause rupture, we find that deformation takes place in a direction tangential to the annual rings, and that failure occurs by a local buckling of the fibres over the whole of a plane which is perpendicular to the annual rings and inclined to the direction of pressure. This is true for all timbers, true whether the medullary rays are more or less strongly marked, and true whatever the proportions of the cross-sections subjected to this compressive stress.

As already mentioned, the proportions of the cross-sections adopted in these tests were generally in the ratio of 2 to 1 . Fig. 2 is a block of Oak cut with broad longitudinal sides tangential, and arranged so as to exhibit one of these sides $\frac{7}{8}$ normal size. It shows this local buckling taking place in two planes more or less equally inclined to the direction of pressure, each fibre being displaced tangentially, but not in a radial direction. Fig. 3 is a block of Ash similarly cut and similarly placed, but here the buckling is shown taking place in a single plane, and this is the more general case. As is always the case, the fibres are displaced tangentially, that is, in the plane of the paper, and the slip extends across the greatest breadth of the test piece. To emphasise this fig. 4 is shown. The broad longitudinal sides of the Ash piece are cut radial, and one is exhibited. With the buckling the fibres have moved tangentially as before, or in a plane perpendicular to the paper, and there is no movement in the radial direction. The same characteristic is illustrated in the case of Boxwood by figs. 5 and 6 . There two views of two separate blocks, cut with the broad sides tangential and radial respectively, are shown, and the slip in the tangential direction is evident, with no movement in a radial direction. 


\section{(b) Cause of Characteristic Failure.}

The reason why the buckling of the wood fibres invariably takes place in a tangential direction is better seen on examining the section of the timbers under the microscope.

The normal appearance of Oak when examined thus is shown by the micro-photographs figs. 7, 8, 9, and 10 . Fig. 7 is a normal radial section showing a side view of a medullary ray seven cells deep. Fig. 8 is a normal transverse section at zone of demarcation between autumn wood of one year and spring wood of the next. Two narrow or secondary medullary rays are shown in plan, and appear as single rows of cells. The more general appearance of the normal transverse section is given in fig. 9, where the magnification is less and a larger portion of the section is seen. The great size of the tracheide compared with that of the wood fibres should be kept in mind for comparison with the section, say, of Boxwood.

But for our purpose possibly the most instructive section is that of fig. 10, in which a normal tangential section is given, showing cross-sections of the cells of the medullary rays, broad and narrow, with wood fibres and parenchyma running longitudinally and sinuously between the groups of ray cells.

If the cross-section of the trunk of a tree is viewed superficially, it might be regarded as made up of a number of thin concentric cylinders continuous throughout the length of the tree and all glued together. Each of these thin cylinders represents an annual ring which is made up of wood fibres principally, the medullary rays dividing it radially, like the joints between the staves of an ordinary barrel. When subjected to longitudinal compressive stress, it would seem as if any buckling that took place in the wood fibres would be in a radial direction.

But, as will readily be seen from fig. 10 , the joints, that is the medullary rays, are not continuous throughout the length of the tree, nor even for a very small portion of it. From the radial section of fig. 7 we see that the wood fibres appear perfectly straight and vertical ; but from the tangential section, fig. 10, we learn that they have a sinuous displacement in the tangential plane, zigzagging their vertical path round the cells of the medullary rays. "This amounts to an "initial set" in a column subjected to end pressure, and failure consequently ensues in the plane containing that initial set.

This is well illustrated in the micro-photographs of wood tested to destruction in this way. Fig. 11 is a general view of a tangential longitudinal section of fractured Oak, and shows that, though failure has occurred to a small degree at the apparently weaker tracheæ, the principal yield has been along a line where the cohesion between the wood fibres and the medullary rays has been the only resistance to the tendency of the fibres to buckle. This is shown to a greater magnification in fig. 12, where the wood fibres are clearly seen leaving the medullary rays. 
We would thus conclude that, even though the cohesion between the wood fibres and the medullary rays was equal to the cohesion between two wood fibres radially adjacent, the mere fact of the initial set would be sufficient to start the buckling in a tangential direction.

The micro-photographs figs. 13-18 prove that what has been said of Oak applies equally to the other woods under investigation. Fig. 13 is a normal transverse section of Ash and is comparable to tig. 9 (Oak), but, being to a three times greater magnification, it is evident that, while the medullary rays and wood fibres are not greatly different, the size of the tracheides is only about one-third of that of Oak. Fig. 14 is a corresponding section of Box, and this, being to the same magnification as fig. 13, shows that here the tracheides are greatly diminished in size, and that the wood fibres are smaller and more solid when compared with either Oak or Ash. Fig. 15 is a normal tangential section of Ash, exhibiting the sinuous form of the wood fibres, and becoming, as shown in fig. 16, the source of weakness when subjected to longitudinal stress.

Figs. 17 and 18 are a corresponding pair of tangential sections of Box, and show that, in spite of the greatly multiplied number of tracheides, smaller in diameter of course, it is still the cohesion between the medullary rays and wood fibres that is at fault.

\section{Longitudinal Tensile Stress.}

\section{Characteristic Failure and its Cause.}

When the longitudinal stress is of a tensile nature the fracture shows certain characteristics. In fig. 19 we have a set of Oak strips $\frac{7}{8}$ natural size, which have been fractured by direct tension. The two upper specimens, one exhibiting its broad side, and the other its narrow side, were cut with their broad sides tangential, while the two lower ones were cut with their broad sides radial. Both $(b)$ and $(c)$ show a tangential face, and the fracture is a ragged one, tearing through wood fibres and then following the planes of the medullary rays, where evidently it meets with the least resistance. $(a)$ and $(d)$ are specimens with their radial faces exposed, and show an abrupt break extending more or less straight across this face.

From this it appears that there is little or no slip between the annual rings or wood fibres radially adjacent, but that a considerable slip takes place between the medullary rays and their adjacent fibres.

Figs. 20 and 21 prove that this is not peculiar to the Oak alone. The latter represents an Ash strip, $\frac{4}{5}$ natural size, and shows the slips along the planes of the medullary rays. Although no illustration is given, the radial face had the usual abrupt break. The former represents specimens of Boxwood, where, though the medullary rays are not nearly so prominent, the same kind of fracture occurs. $(\alpha)$ and (b) of fig. 20 exhibit tangential faces and the slip along the rays, while $(c)$ with its radial face shows the tear across. 


\section{Microscopic Sections.}

Radial sections of specimens tested in tension do not give us enlightenment, as they exhibit only an abrupt break of the fibres. Tangential sections, however, show the characteristic slip between the cells of the medullary rays and the adjacent tissues, proving the weakness of their adhesion at that part.

Fig. 22 is a tangential section of Oak fractured by longitudinal tension, while fig. 23 is a similar section of Boxwood.

\section{Cross-breaking.}

One naturally looks for similar results where similar stresses are induced, as in the case of timber used as beams and tested by means of cross-breaking.

A typical example is that of fig. 25, which shows an Oak beam fractured by this means, the tangential face being exhibited. The beam was laid on a radial face, supported at two ends and loaded in the middle. The ragged break on the tensional side of the beam is similar to what we have already noticed in connection with the direct tension experiments.

The specimen of box seen in fig. 24 also shows the same characteristic, and is even a better example on the tension side of this kind of break than the specimen fractured in direct tension.

The fracture of beams which have been laid on a tangential face, and which are shown exposing a radial face, is sharp, with no evidence of slip taking place by one annual ring sliding past another.

Fig. 26 shows this in the case of Oak, and fig. 27 in that of Ash fractured under similar conditions. In addition, the upper portion shows the bulging out tangentially due to the compression of the applied load and the induced compression along the axis of the beam. This is not usually so pronounced.

The micro-photographs from beams fractured by cross-breaking are similar to those obtained from direct stress experiments. Fig. 29, from a section on the upper or compressive side of a beam, exhibits features similar to those in the first stage of an ordinary compression test.

Fig. 30 shows an enlargement of a portion cut from the lower or tension part of a beam, and since the section is a tangential one, it makes it quite clear that the parting of the tissues follows the groups of ray cells.

Fig. 31 is given for the purpose of showing the effect of end compression on a test piece which contains the centre of the log, and is arranged to exhibit a transverse section. The movement under stress is a tangential one similar to what would be got by a twisting moment combined with an end thrust, one portion of the test piece being rotated past the other, but having the centre of the tree as the common axis of rotation. 
One or two more illustrations are here given to show the features of rupture caused by stresses across the grain.

Fig. 28 is that of two blocks of Oak crushed in a tangential direction, the one on the right to a greater degree than the other. The failure has been as in direct compression along a plane making an angle with the direction of stress, but that plane is composed of a series of steps or slips in each case along the lines of the medullary rays. Any severance that takes place along the zones of spring wood is the consequence of this initial slip.

\section{STRENGTHS.}

In order to obtain a comparison of the strengths of the timbers when cut with the greater dimensions of the cross-section radial or tangential, experiments were made in the determination of (1) modulus of elasticity, by cross-bending; (2) rupture load by compression; (3) by tension ; (4) by cross-breaking.

\section{Modulus of Elasticity by Cross-bending.}

1. Beams of Oak, Ash, and Box woods were cut of a length sufficient to allow 3 feet span, the approximate sections being: Oak, 3 inches by $1 \frac{1}{2}$ inch; Ash, $3 \frac{5}{8}$ inches by $1 \frac{5}{8}$ inch; Box, 2 inches by 1 inch to $2 \frac{5}{8}$ inches by $1 \frac{1}{8}$ inch; and there were as many test pieces as it was possible to eut from the section of a single trunk of each timber.
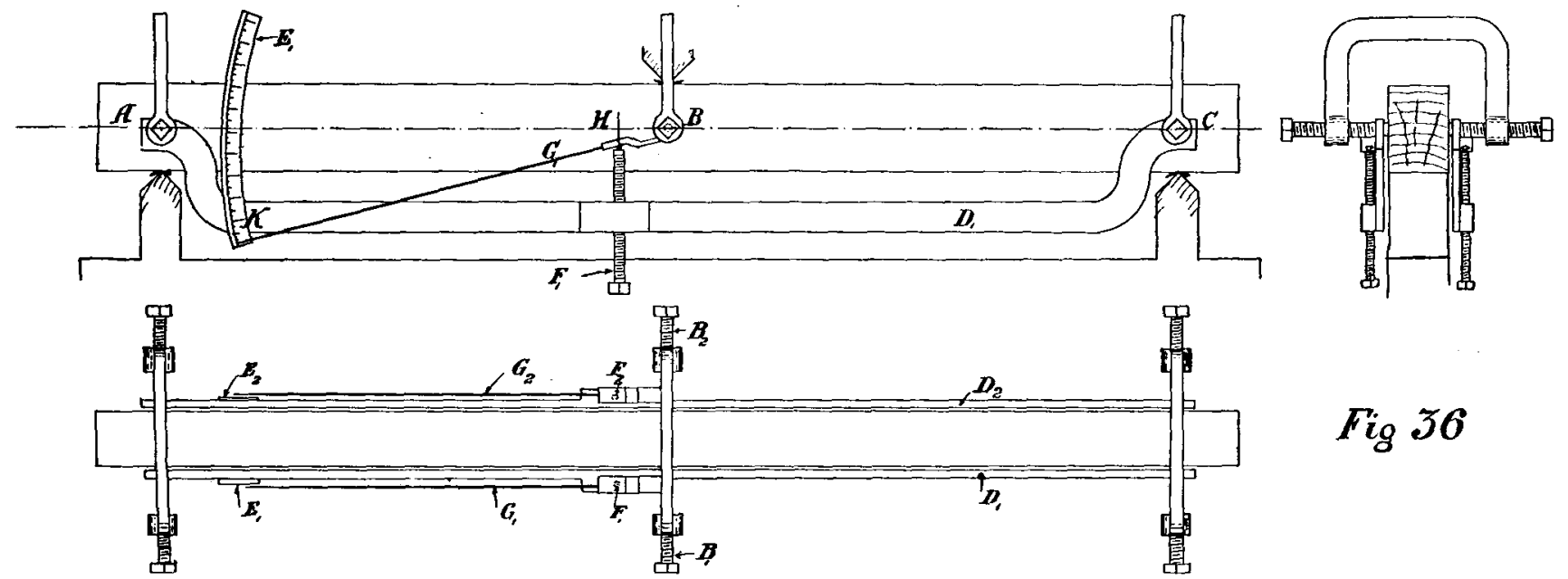

The form of extensometer was that shown in fig. 36, and was devised by the author. To obtain the true deflection, shackles were fixed to the neutral axis of the beam at $A$, $\mathrm{B}, \mathrm{C}$ by means of woor screws. The screws at $\mathrm{A}$ and $\mathrm{C}$ supported the carriers $\mathrm{D}_{1}$ and $\mathrm{D}_{2}$, and to them in turn were attached scales $\mathrm{E}_{1}$ and $\mathrm{E}_{2}$, and also screws $\mathrm{F}_{1}$ and $\mathrm{F}_{2}$, the latter acting as fulcrums for the magnifying levers $G_{1}$ and $G_{2}$, one being placed at either side of the beam. The screws of the shackle $B$, which is placed in the centre of the span immediately underneath the centre of the load $\mathrm{W}$, bear on the end of the 
magnifying lever. Thus any deflection taking place at the centre of the beam B is magnified in the ratio $\frac{\mathrm{HK}}{\mathrm{HB}}$ ( 8 in this particular apparatus). The scales $\mathrm{E}$ are so graded that the actual deflection is at once read off. With this arrangement any error due to crushing of the timber by the knife-edges is eliminated, the actual deflection of the neutral axis is obtained, and by the use of two scales placed one on either side of the beam, both being read and the mean taken, any inequality of pressure due to want of alignment between timber and testing machine is counteracted.

The deflections were measured with the beam resting first on its radial face and then on its tangential, and the formula by which the modulus was determined was $\mathrm{E}=\frac{\mathrm{WL}}{4 b d^{3} \delta}$.

Greatest dimension tangential :-

OAK.

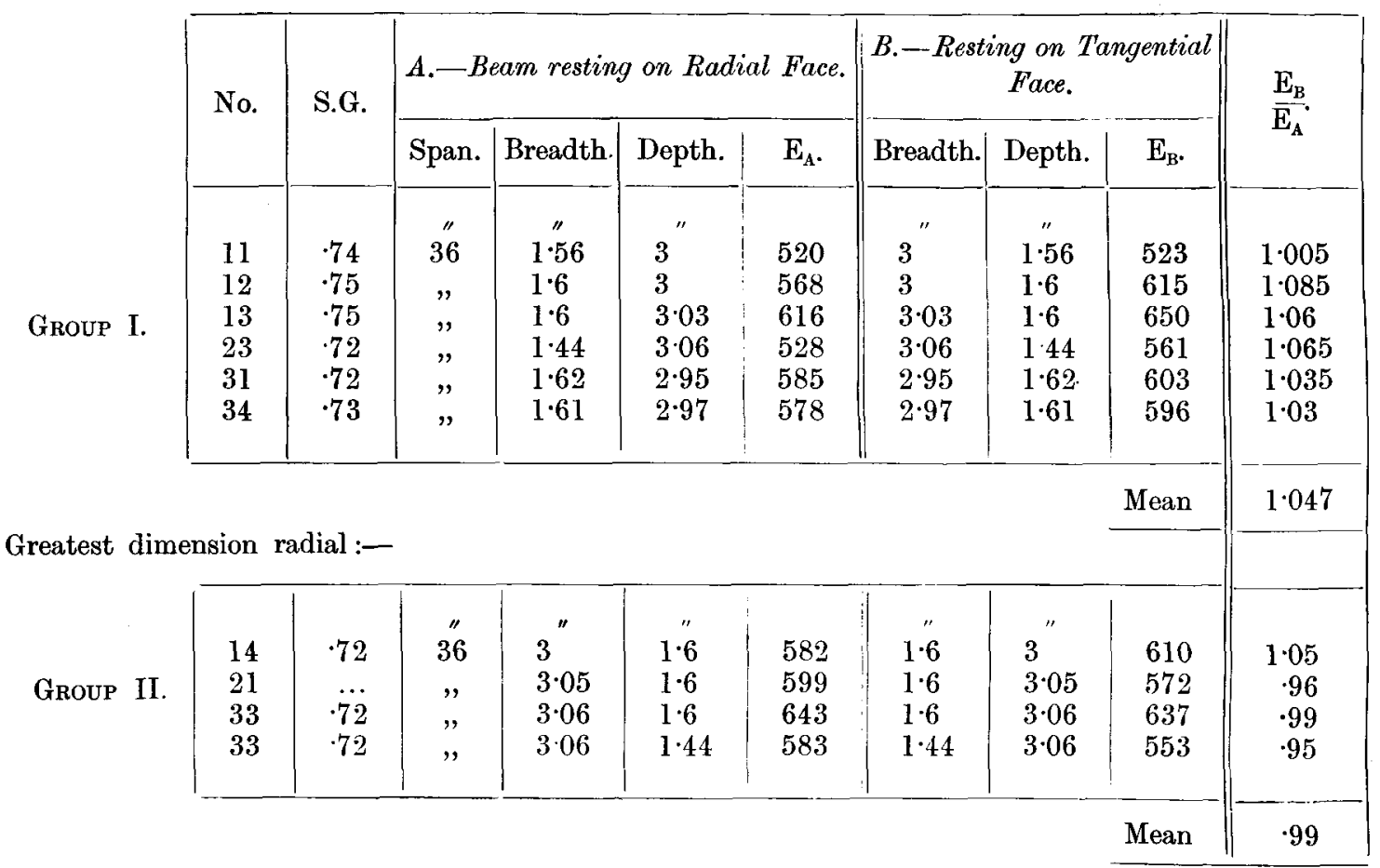

From Group I. it would appear as though position B possessed greater stiffness compared with A, but Group II. shows a slight advantage in the other direction. A modification, however, ought to be made in B of Group I. and A of Group II. on account of the beams in these cases being comparatively broad and shallow, and therefore possessing a greater degree of stiffness. Allowing for this, in both cases the advantage may be said to lie with the beam resting on its tangential face-to the extent, however, of only 2 or 3 per cent. Other Oak experiments bear this out, though, where knots or decided flaws obviously affect the results, they have been left out.

The following were some of the results obtained with Ash and Box :- 
Ash.

Greatest dimension tangential :-

\begin{tabular}{|c|c|c|c|c|c|c|c|c|}
\hline \multirow{2}{*}{ No. } & \multirow{2}{*}{ Span. } & \multicolumn{3}{|c|}{ A.-Beam on Radial Face. } & \multicolumn{3}{|c|}{$\begin{array}{c}\text { B.-Beam on Tangential } \\
\text { Face. }\end{array}$} & \multirow{2}{*}{$\frac{\mathrm{E}_{\mathrm{B}}}{\mathrm{E}_{\mathrm{A}}}$} \\
\hline & & Breadth. & Depth. & $\mathbf{E}_{\mathbf{A}}$ & Breadth. & Depth. & $\mathbf{E}_{\mathbf{B}}$ & \\
\hline $\begin{array}{l}33 \\
31\end{array}$ & $\begin{array}{l}36 \\
36\end{array}$ & $\begin{array}{c}1 \cdot 65 \\
1 \cdot 65\end{array}$ & $\begin{array}{l}\quad " \prime \\
3 \cdot 625 \\
3 \cdot 63\end{array}$ & $\begin{array}{l}565 \\
736\end{array}$ & $\begin{array}{l}3 \cdot 625 \\
3 \cdot 63\end{array}$ & $\begin{array}{c}\prime \prime \\
1.65 \\
1.65\end{array}$ & $\begin{array}{l}628 \\
868\end{array}$ & $\begin{array}{l}1 \cdot 11 \\
1 \cdot 18\end{array}$ \\
\hline \multicolumn{8}{|c|}{ Greatest dimension radial :- - } & $1 \cdot 145$ \\
\hline $\begin{array}{l}12 \\
15\end{array}$ & $\begin{array}{l}36 \\
36\end{array}$ & $\begin{array}{l}3 \cdot 55 \\
3 \cdot 6\end{array}$ & $\begin{array}{l}1 \cdot 87 \\
1 \cdot 65\end{array}$ & $\begin{array}{l}948 \\
961\end{array}$ & $\begin{array}{l}1 \cdot 87 \\
1 \cdot 65\end{array}$ & $\begin{array}{l}3 \cdot 55 \\
3 \cdot 6\end{array}$ & $\begin{array}{l}894 \\
842\end{array}$ & $\begin{array}{l}.945 \\
.875\end{array}$ \\
\hline \multirow{2}{*}{\multicolumn{8}{|c|}{ Greatest dimension tangential :- }} & $\cdot 91$ \\
\hline & & & & & & & & \\
\hline $\begin{array}{r}4 \\
11\end{array}$ & $\begin{array}{l}36 \\
36\end{array}$ & $\begin{array}{l}1 \cdot 18 \\
1 \cdot 07\end{array}$ & $\begin{array}{l}2 \cdot 08 \\
2 \cdot 00\end{array}$ & $\begin{array}{l}630 \\
725\end{array}$ & $\begin{array}{l}2 \cdot 08 \\
2 \cdot 00\end{array}$ & $\begin{array}{l}1 \cdot 18 \\
1 \cdot 07\end{array}$ & $\begin{array}{l}915 \\
875\end{array}$ & $\begin{array}{l}1 \cdot 45 \\
1 \cdot 21\end{array}$ \\
\hline \multicolumn{8}{|c|}{ Greatest dimension radial :- } & $1 \cdot 33$ \\
\hline $\begin{array}{r}2 \\
10\end{array}$ & $\begin{array}{l}36 \\
36\end{array}$ & $\begin{array}{l}2 \cdot 65 \\
2 \cdot 32\end{array}$ & $\begin{array}{l}1 \cdot 16 \\
1 \cdot 14\end{array}$ & $\begin{array}{l}808 \\
930\end{array}$ & $\begin{array}{l}1 \cdot 16 \\
1 \cdot 14\end{array}$ & $\begin{array}{l}2 \cdot 65 \\
2 \cdot 32\end{array}$ & $\begin{array}{l}604 \\
782\end{array}$ & $\begin{array}{l}.75 \\
.84\end{array}$ \\
\hline & & & & & & & Mean & $\cdot 795$ \\
\hline
\end{tabular}

In the Ash and Box experiments, whether $\frac{\mathrm{E}_{\mathrm{B}}}{\overline{\mathrm{E}}_{\mathrm{A}}}$ is greater or less than 1 depends mainly on whether the broad face of the beam is vertical or horizontal; but, making allowance for this, there still remains an advantage in stiffness in favour of laying the tangential side horizontal, of about 6 or 7 per cent.

Two conclusions may be drawn from these results:-

(a) In each case an advantage, though it may be slight, exists in placing a timber beam on a tangential face, due probably to the medullary rays being now vertical, and therefore not affecting the stiffness.

(b) For beams of given proportions of section, say 2 to 1 , the effect of placing the beam on a broad or narrow face, and using the ordinary formula to make them comparable, seems to be decidedly in favour of placing them on the broad side. The advantage ranges from 3 per cent. in Oak, 9 per cent. in Ash, to 20 per cent. in Box. Evidently the explanation of this lies in the anti-clastic curvature of the beams. In addition to the bending which takes place in the vertical plane parallel to the axis of 
the beam, and which is caused by the loading, we have the lateral widening and contracting of the section in compression and tension respectively due to the induced stresses. In deep, narrow beams this process is not greatly interfered with, but in broad, shallow ones there is a constraint due to the method of loading. The more elastic a material is, the less will this constraint be felt. Possibly the presence of very pronounced medullary rays allows the Oak to accommodate itself better than the Ash, and the latter in turn more readily than the Box.

If we assume that all lateral strain is prevented, the apparent increase in value of the modulus of elasticity $\mathrm{E}$, compared with the case where there is no such restraint, is represented by $\frac{\sigma^{2}}{\sigma^{2}-1}$, where $\frac{1}{\sigma}=$ PoIsson's ratio. If $\frac{1}{\sigma}=\cdot 25$ for Ash and $\cdot 4$ for Box, then the ratio $\frac{\mathrm{E} \text { (flat) }}{\mathrm{E} \text { (deep) }}=1.06$ for Ash and $1 \% 2$ for Boxwood. As the author has had no opportunity of measuring Porsson's ratio for these materials, it is impossible to say how far such an assumption is justified.

\section{Compression Tests.}

In these tests half the number of specimens were cut with the broad side of the section tangential, and half with that side radial, and each series consisted of varying lengths. The lengths $(l)$ were simple multiples of the narrow dimension $(k)$, and ranged from $l=k$ to $l=13 k$.

Fig. 33 shows a set of Oak blocks cut with broad side tangential and exhibiting the radial side, after having been subjected to longitudinal compression. The five shortest blocks, $l=k$ to $l=8 k$, show no sign of bending, but have the usual local buckling taking place tangentially, as has been previously noticed. $6(l=10 k)$ and $7(l=12 k)$ have both a compound failure, consisting of the usual local crumpling and of bending in the plane of the paper, which is of course the plane of the least dimension, $k$.

A similar set of blocks, but cut with the broad side radial and showing the tangential side, is illustrated in fig. 34. Here the compound fracture is slightly shown in the fourth block $(l=6 k)$, which is much earlier than in the other series. This is to be expected, for the local buckling and the buckling of the test piece as a whole take place in the one plane, that of the paper. Although this appears on shorter lengths than in the other series, there is evidently no great difference in the crushing stress required. The extra inducement to bend only comes into play after the local buckling has taken place and Sailure has begun. Only in pieces of very short lengths $(l=k$ or $l=2 k)$ is there any advantage, and then it rests with those cut with the broad side tangential.

The Ash and Box tests show very similar results, so it is not necessary to illustrate them.

Plotting the results obtained with these timbers, and using the crushing pressure per square inch as ordinates and the ratio $\frac{l}{k}$ as abscissæ, it is found that, within the limits 
of length investigated and for rectangular sections, the maximum fracture stress per square inch, $p$, may be represented by $p=\frac{f_{c}}{1+\alpha_{\bar{k}}}$ instead of the more common RankineGordon formula, $p=\frac{f_{c}}{1+\alpha_{\bar{k}^{2}}}$, where

$\alpha=$ constant depending on material and method of holding test piece.

$l=$ length of test piece.

$k=$ least dimension of cross-section.

$f_{c}=$ maximum crushing stress per square inch determined from a test piece when $l=k$.

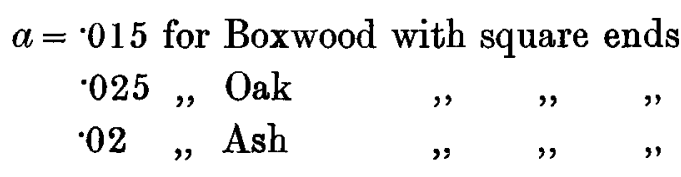

Fig. 37 shows the results of the tests plotted in this way.

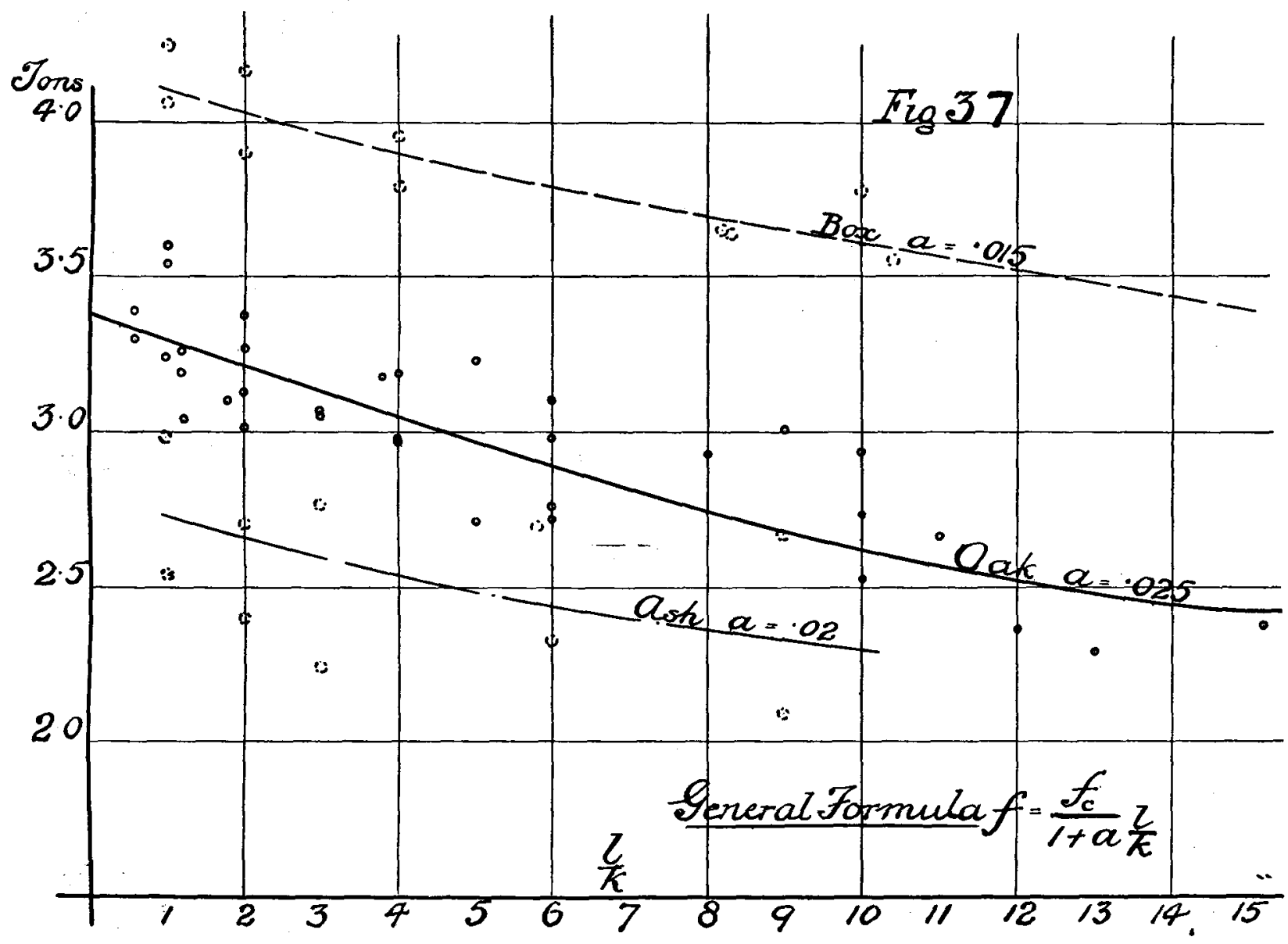




\section{Tension Tests.}

From the results of the tests for elasticity and in compression it was evident that no great difference of stress would arise in the tension and shearing tests.

The specimens in tension were of rectangular section, $1^{\prime \prime}$ to $1 \frac{7^{\prime \prime}}{8}$ wide by $\frac{1}{4}^{\prime \prime}$ to $\frac{5^{\prime \prime}}{16}$ thick, with enlarged ends.

The average results were as follows :--

\begin{tabular}{|c|c|c|c|c|c|c|c|c|c|}
\hline \multirow{2}{*}{$\mathrm{O}_{\mathrm{AK}}$} & \multicolumn{3}{|c|}{ broad side radial } & \multicolumn{3}{|c|}{$7 \cdot 05$ tons per sq. in. } & \multirow{2}{*}{$\begin{array}{c}\text { Maximum } \\
",\end{array}$} & \multirow{2}{*}{\multicolumn{2}{|c|}{$\begin{array}{l}7 \cdot 45 \text { tons. } \\
7 \cdot 05 \quad \text { " }\end{array}$}} \\
\hline & , & , & tangential & $6 \cdot 93$ & $"$ & $"$ & & & \\
\hline \multirow{2}{*}{ AsH } & $"$ & " & radial & $8 \cdot 81$ & " & " & "' & $9 \cdot 38$ & $"$ \\
\hline & " & ", & tangential & $8 \cdot 28$ & , & ," & ", & $9 \cdot 13$ & $"$ \\
\hline \multirow[t]{2}{*}{ BoxwOOD } & $"$ & $"$ & radial & $9 \cdot 47$ & $"$ & $"$ & ", & $9 \cdot 71$ & ", \\
\hline & ", & , & tangential & $8 \cdot 8$ & $"$ & , & , & $10 \cdot 2$ & ", \\
\hline
\end{tabular}

Here a slight balance is shown in favour of the broad side being radial, though in the Boxwood tests the maximum value was reached by a specimen cut with its broad side tangential. Owing to the careful selection of the timber, the results were very uniform.

\section{Shearing.}

The test pieces here were cylindrical in shape and of $1 \frac{1}{4}$ inch diameter. In the case of Oak the shear was measured radially, tangentially, transversely, and obliquely.

\begin{tabular}{|c|c|c|c|c|c|}
\hline & Radial. & Tangential. & Transverse. & Oblique. & \\
\hline Oak, average & - $\cdot 48$ & $\cdot 6$ & $1 \cdot 04$ & $\cdot 8$ & tons per sq. in. \\
\hline Ash . . & $\cdot 5$ & $\cdot 6$ & 1.03 & & \\
\hline Box & . .75 & $\cdot 8$ & $1 \cdot 24$ & & \\
\hline
\end{tabular}

According to these results, there seems to be a greater resistance to shearing along the rings than to shearing along the lines of the medullary rays, a result which, however, we would naturally expect from the previous experiments.

\section{Cross-breaking.}

It has been the practice to measure the stress or strength factor in cross-breaking by the well-known formula,

where $\mathrm{W}=$ central breaking load,

$$
f=\frac{3}{2} \frac{W L}{b d^{2}}
$$

$\mathrm{L}=$ length of span,

$b=$ breadth, and

$d=$ depth of rectangular section.

This formula is based on the theory of the elastic bending of beams, and gives a value of " $f$ " for the rupture stress which in timber is too great for the ultimate compressive stress, and too small for the ultimate tensile stress of the material. If, however, the value of $\mathrm{W}$ inserted in the above formula be the central load at the limit of proportionality of deflection to load, then the stress so calculated agrees 
fairly well with the crushing strength as got from ordinary longitudinal compression, but has no relation to the tensile strength. This is due to the fact that in timber the elastic limit is about 6 of the breaking load, and also that the ultimate compressive strength is approximately 6 of the calculated strength factor. There is thus no direct connection. But, on the assumption that the limit of elasticity varies directly as the breaking load and therefore as the modulus of rupture, the value of the latter is usually considered as a good indication of the compressive strength of the timber.

In the tests for elasticity we have seen that the modulus varies with the position of the section, being greater when resting on the broad side than when on the narrow side. We would expect, therefore, that the stress at the point of ultimate fracture would show a corresponding difference. But the tests hardly bear this out. Some of the results have been grouped in pairs, and comparisons are made between their moduli of elasticity and of rupture under similar and dissimilar conditions, but these ratios are not constant. $\mathrm{E}_{\mathrm{H}}$ and $\mathrm{E}_{\mathrm{v}}$ are Young's modulus with broud side horizontal and vertical respectively, and $f_{\mathrm{H}}$ and $f_{\mathrm{v}}$ are the calculated extreme fibre stresses obtained under similar conditions.

Ash.

\begin{tabular}{|c|c|c|c|c|c|c|c|c|}
\hline $\begin{array}{c}\text { Test } \\
\text { " }\end{array}$ & $\left.\frac{31}{12}\right\}$ & $\begin{array}{c}\text { Broad } \\
\quad,\end{array}$ & $\begin{array}{c}\text { side } \\
, y\end{array}$ & $\begin{array}{c}\text { tangential } \\
,\end{array}$ & $\frac{E_{v}}{E_{v}}=\cdot 82$ & $\frac{\mathrm{E}_{\mathrm{H}}}{\mathrm{E}_{\mathrm{H}}}=\cdot 915$ & $\frac{\mathrm{E}_{\mathrm{H}}}{\mathrm{E}_{\mathrm{V}}}=\cdot 97$ & $\frac{f_{\mathrm{H}}}{f_{\mathrm{V}}}=1 \cdot 15$ \\
\hline $\begin{array}{l}\text { " } \\
\text { " }\end{array}$ & $\left.\begin{array}{l}33 \\
15\end{array}\right\}$ & ", & " & $\begin{array}{c}\text { radial } \\
\quad,\end{array}$ & $n=\cdot 67$ & $\eta=.65$ & $n=\cdot 745$ & $n=1$ \\
\hline$"$ & $\left.\frac{31}{33}\right\}$ & ", & ", & $\begin{array}{l}\text { tangential } \\
\text { radial }\end{array}$ & $n=1 \cdot 3$ & $n=1 \cdot 38$ & & $\frac{f_{\mathrm{H}}}{f_{\mathrm{H}}}=1 \cdot 15$ \\
\hline $\begin{array}{l}" \\
",\end{array}$ & $\left.\frac{12}{15}\right\}$ & " & $"$ & $\begin{array}{l}\text { tangential } \\
\text { radial }\end{array}$ & $\eta=1.07$ & $"=.98$ & & $\frac{f_{\mathrm{v}}}{f_{\mathrm{v}}}=1$ \\
\hline
\end{tabular}

Boxwoon.

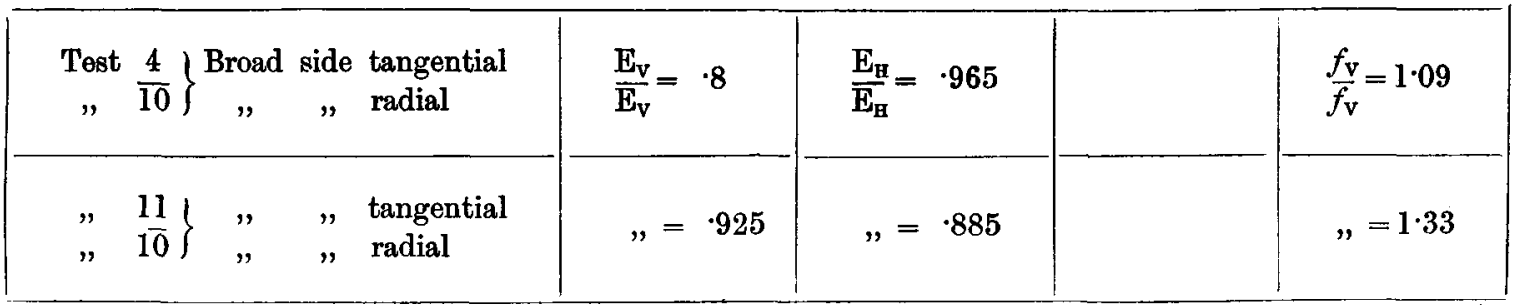

A high Young's modulus showing a high degree of stiffness is quite compatible with a comparatively low ultimate strength, as the presence of any flaw, though not evident in the elastic stage, will be shown by a low breaking load. Thus beams which show the 
lower modulus of elasticity of the pair may show the higher strength factor. Before próceeding, then, to determine extreme fibre stresses by the ordinary formula, an attempt has been made by modifying it to connect up the stresses induced at the point of ultimate fracture in cross-breaking with the ultimate stresses in direct compression, tension, and shear.

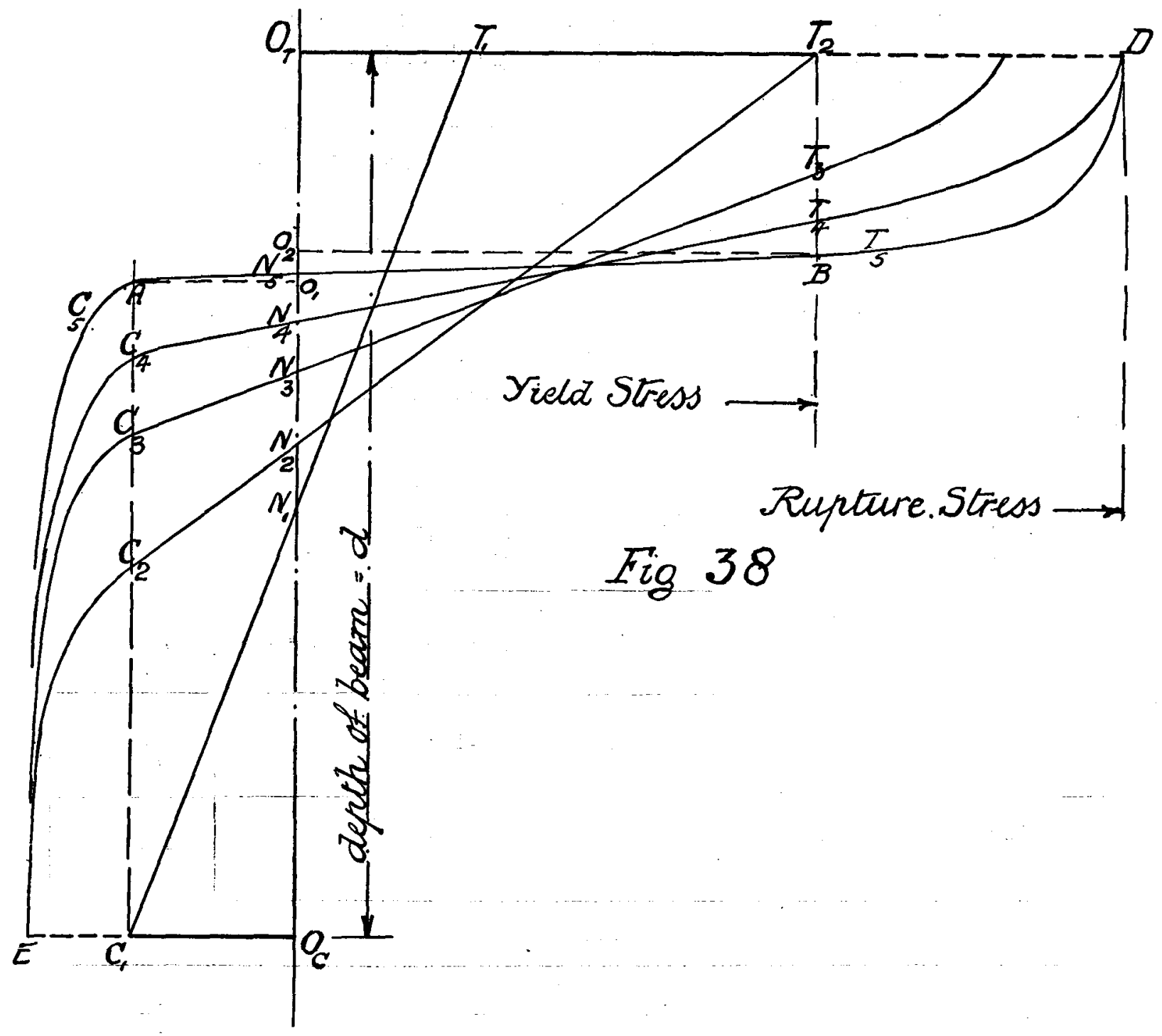

The probable development of the stress diagram of a beam of rectangular section, supported at two ends and loaded in the middle, is shown in fig. 38 for the typical case of an Ash beam. $\mathrm{C}_{1} \mathrm{~N}_{1} \mathrm{~T}_{1}$ is the stress diagram up to the elastic yield-point $\mathrm{C}_{1}$ of the extreme fibres on the compression side. During the second period elastic yield continues on the tension side until the extreme fibres on that side also reach the elastic limit $T_{2}$. Meanwhile, since the compression strain of the extreme fibres on the other side has been mostly plastic, the compression stress has not increased proportionately 
to the strain, and on reaching the fracture value $\mathrm{E}$ no further increase of stress takes place in the extreme fibres, any further increment of Joad being met by the adjacent internal fibres becoming stressed in turn beyond the elastic limit to the fracture point. Since the total stress area across the section remains zero, there must follow a deviation of the neutral axis towards the tension side, and an increase of the compression area to keep pace with the tension area, and $\mathrm{EC}_{2} \mathrm{~N}_{2}{ }^{\prime} \mathrm{T}_{2}$ represents the new diagram.

From period 2 to 4 , with increase of load, the extreme tension fibres are being stretched plastically till they reach fracture point $\mathrm{D}$ with a stress diagram $\mathrm{EC}_{4} \mathrm{~N}_{4} \mathrm{D}$. Then, as on the compression side, the stress is transmitted to the internal fibres by cohesion until they too reach their fracture point, and this further stage would be represented by $\mathrm{EC}_{5} \mathrm{~N}_{5} \mathrm{D}$. The limits that can be set to this process are $(a)$ when the tension and compression stress areas assume the rectangular form, and are equal to each other, the ordinates in each case being equal to the ultimate breaking stresses of the material in direct tension and compression respectively, and $(b)$ when the cohesion between adjacent fibres measured from the neutral axis outwards is not sufficient to withstand the shear induced by the resisting moment of the beam, which is at a maximum along the neutral axis of the beam.

The first alternative occurs only when the induced shear has not risen to the shear fracture value of the material, before the compression and tension stress areas assume approximately the rectangular form ; the second, when the induced shear reaches the value of the shearing strength, even though the maximum compressive and tensile strengths may not be reached.

\section{Maximum Fibre Stress.}

Jet $\mathrm{EC}_{5} \mathrm{~N}_{5} \mathrm{~T}_{5} \mathrm{D}$ represent the stress diagram at instant of fracture.

$\mathrm{AO}_{1}=\mathrm{C}_{1} \mathrm{O}_{\mathrm{C}}=$ elastic limit in compression $=\mathrm{K}_{c}$ ultimate compressive stress.

$\mathrm{BO}_{2}=\mathrm{T}_{2} \mathrm{O}_{\mathrm{r}}=\quad, \quad, \quad$ tension $=\mathrm{K}_{t} \quad ; \quad$ tensile ,

$\mathrm{O}_{1} \mathrm{O}_{2}=$ fibres still being stressed elastically.

$\mathrm{O}_{2} \mathrm{O}_{\mathrm{T}}=$ tension fibres stressed plastically.

$\mathrm{O}_{1} \mathrm{O}_{\mathrm{c}}=$ compression fibres stressed plastically.

$\mathrm{BD}$ and $\mathrm{AE}$ are assumed to be parabolic curves.

Tension area $\mathrm{O}_{\mathrm{T}} \mathrm{N}_{5} \mathrm{BD}=$ compression area $\mathrm{O}_{\mathrm{C}} \mathrm{N}_{5} \mathrm{AE}$.

The number of fibres which are stressed elastically may be reckoned so small that $A B$ may be assumed to coincide with the final neutral axis, $N_{5}$.

Let $b=$ breadth of beam and $d=$ depth; then

Tension area $=b \times \mathrm{U}_{\mathrm{T}} \mathrm{N}_{5}$ \{elastic stress $+\frac{2}{3}$ (fracture stress - elastic stress $\left.)\right\}$ $=b \times 0_{\mathrm{T}} \mathrm{N}_{5}\left\{\mathrm{~K}_{t}\right.$ fracture stress $+\frac{2}{3} \times\left(1-\mathrm{K}_{t}\right)$ fracture stress $\}$ $=b . \mathrm{O}_{\mathrm{T}} \mathrm{N}_{5} \cdot \frac{2+\mathrm{K}_{t}}{3}$ ultimate tensile or fibre stress $=b . \mathrm{O}_{\mathbf{T}} \mathrm{N}_{5} \cdot \frac{\ddot{z}+\mathrm{K}_{t}}{3} t$. 
The neutral axis, if the extreme limit of a rectangular area of stress was reached, would divide the beam inversely as the maximum stresses, i.e. $\frac{O_{\mathrm{T}} \mathrm{N}_{5}}{\mathrm{O}_{\mathrm{C}} \mathrm{N}_{5}}=\frac{c}{\mathrm{~T}}$ and $\frac{\mathrm{O}_{\mathrm{T}} \mathrm{N}_{5}}{d}=\frac{\mathrm{C}}{\mathrm{T}+\mathrm{C}}$; therefore $\mathrm{O}_{\mathrm{T}} \mathrm{N}_{5}=d_{\frac{\mathrm{T}}{\mathrm{T}}+\mathrm{C}}$.

With the stress areas assumed, the position of the neutral axis and the distance between the centres of gravity of the two component stress diagrams will not differ appreciably from that got with a purely rectangular stress diagram.

Therefore,

and similarly

$$
\text { Tension area }=b d \frac{\mathrm{C}}{\mathrm{T}+\mathrm{C}} \times \frac{2+\mathrm{K}_{t}}{3} t
$$

$$
\text { Compression area }=b d_{\overline{\mathbf{T}}+\mathrm{C}} \times \frac{2+\mathrm{K}_{c}}{3} c .
$$

The moment of the internal stresses resisting the external bending moment at the instant of fracture will be :

$$
\begin{aligned}
& \text { Tension stress area } \times \frac{d}{2}=\text { compression stress area } \times \frac{d}{2}=\mathrm{M}, \\
& \therefore \quad b \times d \times \frac{\mathrm{C}}{\mathrm{T}+\mathrm{C}} \times \frac{2+\mathrm{K}_{t}}{3} t \times \frac{d}{2}=b \times d \times \frac{\mathrm{T}}{\mathrm{T}+\mathrm{C}} \times \frac{2+\mathrm{K}_{c}}{3} c \times \frac{d}{2}=\mathrm{M},
\end{aligned}
$$

where $t$ and $c$ are the extreme fibre stresses. For timber, $\mathrm{K}_{t}=\mathrm{K}_{c}=625$ approx. Therefore

$$
t=\frac{2 \cdot 3 \mathrm{M}}{b d^{2}} \cdot \frac{\mathrm{T}+\mathrm{C}}{\mathrm{C}} \text { and } c=\frac{2 \cdot 3 \mathrm{M}}{b d^{2}} \cdot \frac{\mathrm{T}+\mathrm{C}}{\mathrm{T}}
$$

Now, extreme direct stresses for

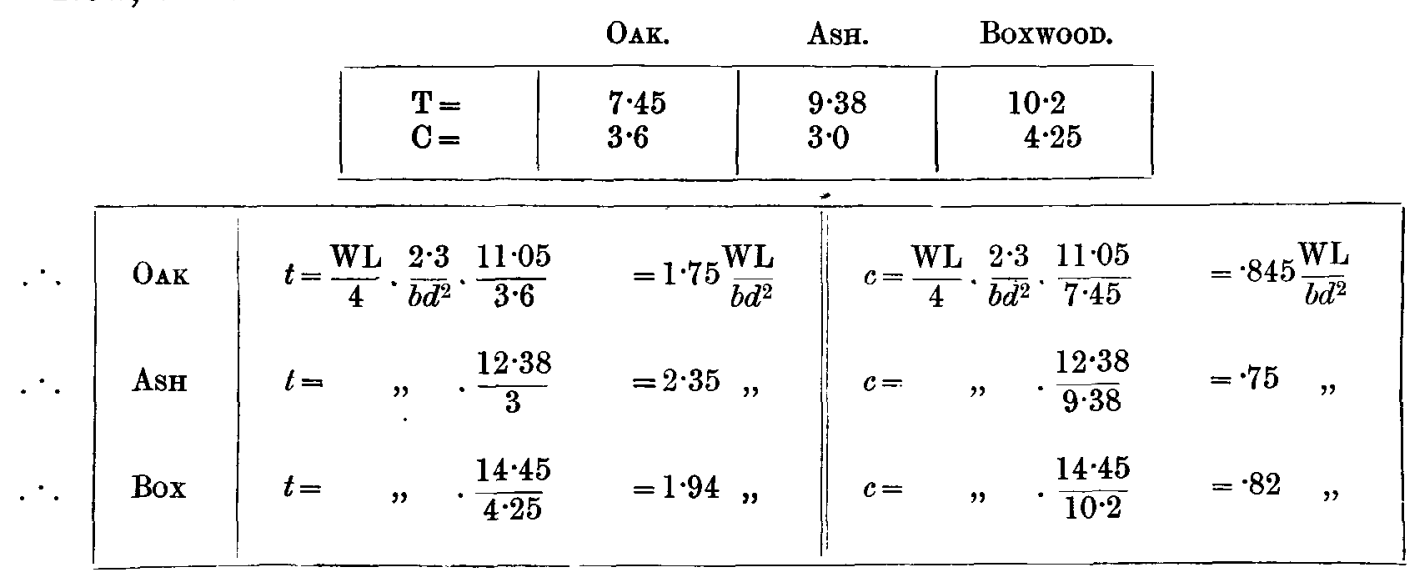

Maximum Shear Stress.

To discover the maximum shear stress, let $t$ and $(t+\delta t)$ be the extreme fibre stresses un two transverse sections of the beam at a distance $\delta x$ apart measured along the axis of the beam. Then

therefore

$$
t=\frac{\mathrm{T}+\mathrm{C}}{\mathrm{C}} \cdot \frac{\mathrm{M}}{b d^{2}} \cdot 2 \cdot 3 \quad \text { and } \quad t+\delta t=\frac{\mathrm{T}+\mathrm{C}}{\mathrm{C}} \cdot \frac{\mathrm{M}+\delta \mathrm{M}}{b d^{2}} \cdot 2 \cdot 3
$$

$$
\delta t=\frac{\mathrm{T}+\mathrm{C}}{\mathrm{C}} \cdot \frac{2 \cdot 3}{b d^{2}} \cdot \delta \mathrm{M} \text { per } \delta x \text { length }
$$


or

$$
\frac{\delta t}{\delta x}=\frac{\delta \mathrm{M}}{\delta x} \cdot \frac{2 \cdot 3}{b d^{2}} \cdot \frac{\mathrm{T}+\mathrm{C}}{\mathrm{C}}=\mathrm{F} \times \frac{2 \cdot 3}{b d^{2}} \cdot \frac{\mathrm{T}+\mathrm{C}}{\mathrm{C}},
$$

where $\mathrm{F}=\frac{\delta \mathrm{M}}{\delta x}=$ shearing force on that section of the beam.

Total difference of tension or longitudinal shear at neutral axis per unit of breadth $=\Sigma_{\overline{\delta x}}^{\delta t}$ from extreme fibre to neutral axis $=\mathrm{S}=$ shearing stress per square inch. Therefore, if fibre stress diagram is rectangular in form,

$$
\mathrm{S}=\Sigma \cdot \frac{\delta t}{\delta x}=\mathrm{F} \cdot \frac{2 \cdot 3}{b d^{2}} \cdot \frac{\mathrm{T}+\mathrm{C}}{\mathrm{C}} \cdot\left(\frac{\mathrm{C}}{\mathrm{T}+\mathrm{C}} \cdot d\right)=\frac{\mathrm{F} \times 2 \cdot 3}{b d} .
$$

But the area of stress diagram has been assumed to be $\frac{2+K_{t}}{3}$ times that of rectangular form, where $K_{t}=625$;

therefore

$$
\mathrm{S}=\frac{7}{8} \times \frac{2 \cdot 3}{b d} \cdot \mathrm{F}=\frac{2 \mathrm{~F}}{b d}=2 \frac{2 \frac{\mathrm{W}}{2}}{b d}=\frac{\mathrm{W}}{b d}
$$

To determine the condition that fracture may equally occur either by tearing or crushing or shearing,

$$
t=k \frac{\mathrm{L}}{d} \cdot \frac{\mathrm{W}}{b d}=k \cdot \frac{\mathrm{L}}{d} \cdot \mathrm{S}
$$

by equations (1) and (2), where $k$ is a constant. If $S$ and $t$ be known, then $\frac{L}{d}$ can be determined, and may be called the critical ratio. With a ratio of length to depth less than this, the presumption is that the fracture will take place by shear; with a ratio greater than this, that the fracture will be caused by tearing or crushing, beginning at the extreme fibres.

The critical ratios, assuming the ultimate direct stresses for $t$ and $\mathrm{S}$, are :-

\begin{tabular}{|c|c|c|}
\multicolumn{1}{c}{ OAK. } & Ast. & Boxwood. \\
\hline \multirow{2}{*}{$\frac{\mathrm{L}}{d}=\frac{t}{\mathrm{~S} k}=\frac{7.45}{6 \times 1.75}=7$} & $\frac{9.38}{9 \times 2.35}=4.4$ & $\frac{10 \cdot 2}{1 \cdot 26 \times 1.94}=4.15$ \\
& to & to \\
& $\frac{9.38}{6 \times 2.35}=6.6$ & $\frac{10 \cdot 2}{8 \times 1.94}=6.15$ \\
\hline
\end{tabular}

In the following tables of the results of experiments, the values of $t, c$, and $\mathrm{S}$ have been worked out from the formulæ (1) and (2), and give a better idea of the relative stresses.

TRANS. ROY. SOC. EDIN., VOL. XLVIII., PART II. (NO. 21). 
OAK.

\begin{tabular}{|c|c|c|c|c|c|c|c|c|c|c|}
\hline Spec. No. & Span. & $b$ & $d$ & $\frac{\mathbf{L}}{d}$. & $\begin{array}{l}\text { Breaking } \\
\text { Load in } \\
\text { Tons. }\end{array}$ & $\begin{array}{c}t=\frac{1 \cdot 75 \mathrm{WL}}{b \bar{d}^{2}} . \\
\text { Tons } \\
\text { per sq. in. }\end{array}$ & $\begin{array}{c}c=\frac{845 W \mathrm{~L}}{b d^{2}} \\
\text { Tons } \\
\text { per sq. in. }\end{array}$ & $\begin{array}{c}\text { Elastic } \\
\text { Fornula, } \\
t=c=1 \cdot 5 \frac{\mathrm{WL}}{b d^{2}}\end{array}$ & $\begin{array}{c}\mathbf{S}=\frac{\mathrm{W}}{b d} \\
\text { Tons } \\
\text { per sq. in. }\end{array}$ & $\begin{array}{c}\text { Direction of } \\
\text { Horizontal } \\
\text { Shear. }\end{array}$ \\
\hline $\begin{array}{l}116 \\
114\end{array}$ & $\begin{array}{l}4 \\
6 \\
6\end{array}$ & $\begin{array}{l}1: 6 \\
1 \cdot 6\end{array}$ & $\begin{array}{l}3 " \\
1 \cdot 95\end{array}$ & $\begin{array}{l}2 \\
3 \cdot 07\end{array}$ & $\begin{array}{l}3 \cdot 38 \\
3 \cdot 15\end{array}$ & $\begin{array}{l}2 \cdot 46 \\
5 \cdot 45\end{array}$ & $\begin{array}{l}1 \cdot 18 \\
2 \cdot 63\end{array}$ & $\begin{array}{l}2 \cdot 12 \\
4 \cdot 68\end{array}$ & $\begin{array}{r}\cdot 70 \\
1 \cdot 01\end{array}$ & Radial. \\
\hline $\begin{array}{l}2224 \\
1431\end{array}$ & $\begin{array}{l}4 \cdot 8 \\
5\end{array}$ & $\begin{array}{r}1 \cdot 2 \\
\cdot 5\end{array}$ & $\begin{array}{l}1 \cdot 6 \\
1 \cdot 58\end{array}$ & $\begin{array}{l}3 \\
3 \cdot 16\end{array}$ & $\begin{array}{l}1.82 \\
1.02\end{array}$ & $\begin{array}{l}4 \cdot 95 \\
7 \cdot 15\end{array}$ & $\begin{array}{l}2 \cdot 39 \\
3 \cdot 45\end{array}$ & $\begin{array}{l}4 \cdot 24 \\
6 \cdot 13\end{array}$ & $\begin{array}{r}\cdot 94 \\
1 \cdot 29\end{array}$ & $"$ \\
\hline $\begin{array}{l}1411 \\
1432\end{array}$ & $\begin{array}{l}6 \\
6\end{array}$ & $\begin{array}{c}1 \cdot 62 \\
\cdot 5\end{array}$ & $\begin{array}{l}1 \cdot 62 \\
1 \cdot 58\end{array}$ & $\begin{array}{l}3 \cdot 75 \\
3 \cdot 78\end{array}$ & $\begin{array}{r}2.08 \\
.96\end{array}$ & $\begin{array}{l}5 \cdot 28 \\
8 \cdot 1\end{array}$ & $\begin{array}{l}2 \cdot 54 \\
3 \cdot 9\end{array}$ & $\begin{array}{l}4 \cdot 53 \\
6 \cdot 93\end{array}$ & $\begin{array}{r}\cdot 80 \\
1.22\end{array}$ & $"$ \\
\hline $\begin{array}{r}2225 \\
115\end{array}$ & $\begin{array}{c}6 \cdot 4 \\
12\end{array}$ & $\begin{array}{l}1 \cdot 2 \\
1 \cdot 6\end{array}$ & $\begin{array}{l}1 \cdot 6 \\
3\end{array}$ & $\begin{array}{l}4 \cdot 0 \\
4 \cdot 0\end{array}$ & $\begin{array}{l}1 \cdot 36 \\
3 \cdot 03\end{array}$ & $\begin{array}{l}4 \cdot 98 \\
4 \cdot 42\end{array}$ & $\begin{array}{l}2 \cdot 4 \\
2 \cdot 13\end{array}$ & $\begin{array}{l}4 \cdot 21 \\
3 \cdot 79\end{array}$ & $\begin{array}{l}\cdot 71 \\
\cdot 63\end{array}$ & $"$ \\
\hline $\begin{array}{r}342 \\
1413\end{array}$ & $\begin{array}{r}12 \\
7\end{array}$ & $\begin{array}{l}1 \cdot 6 \\
1 \cdot 62\end{array}$ & $\begin{array}{l}2 \cdot 97 \\
1 \cdot 62\end{array}$ & $\begin{array}{l}4 \cdot 03 \\
4 \cdot 35\end{array}$ & $\begin{array}{l}3 \cdot 7 \\
2 \cdot 14\end{array}$ & $\begin{array}{l}3 \cdot 08 \\
6 \cdot 3\end{array}$ & $\begin{array}{l}1 \cdot 49 \\
3 \cdot 04\end{array}$ & $\begin{array}{l}2 \cdot 64 \\
5 \cdot 40\end{array}$ & $\begin{array}{l}\cdot 78 \\
83\end{array}$ & $"$ \\
\hline $\begin{array}{l}1433 \\
2226\end{array}$ & $\begin{array}{l}7 \\
8\end{array}$ & $\begin{array}{r}\cdot 5 \\
1 \cdot 2\end{array}$ & $\begin{array}{l}1 \cdot 58 \\
1 \cdot 6\end{array}$ & $\begin{array}{l}4 \cdot 42 \\
5 \cdot 0\end{array}$ & $\begin{array}{r}\cdot 76 \\
1 \cdot 34\end{array}$ & $\begin{array}{l}7 \cdot 45 \\
6 \cdot 1\end{array}$ & $\begin{array}{l}3 \cdot 6 \\
2 \cdot 94\end{array}$ & $\begin{array}{l}6 \cdot 39 \\
5 \cdot 23\end{array}$ & $\begin{array}{l}.96 \\
.70\end{array}$ & $"$ \\
\hline $\begin{array}{l}1434 \\
1435\end{array}$ & $\begin{array}{l}8 \\
9\end{array}$ & $\begin{array}{r}.5 \\
.5\end{array}$ & $\begin{array}{l}1 \cdot 58 \\
1 \cdot 58\end{array}$ & $\begin{array}{l}5 \cdot 08 \\
5 \cdot 72\end{array}$ & $\begin{array}{l}\cdot 67 \\
\cdot 70\end{array}$ & $\begin{array}{l}7 \cdot 55 \\
8 \cdot 85\end{array}$ & $\begin{array}{l}3 \cdot 65 \\
4 \cdot 26\end{array}$ & $\begin{array}{l}6 \cdot 47 \\
7 \cdot 59\end{array}$ & $\begin{array}{l}\cdot 84 \\
\cdot 88\end{array}$ & $"$ \\
\hline $\begin{array}{l}1222 \\
2211\end{array}$ & $\begin{array}{l}4 \cdot 8 \\
9 \cdot 6\end{array}$ & $\begin{array}{c}1 \cdot 57 \\
\cdot 8\end{array}$ & $\begin{array}{r}\cdot 82 \\
1.57\end{array}$ & $\begin{array}{l}5 \cdot 84 \\
6 \cdot 12\end{array}$ & $\begin{array}{r}1 \cdot 05 \\
\cdot 84\end{array}$ & $\begin{array}{l}8 \cdot 25 \\
7 \cdot 2\end{array}$ & $\begin{array}{l}3 \cdot 98 \\
3 \cdot 47\end{array}$ & $\begin{array}{l}7 \cdot 07 \\
6 \cdot 17\end{array}$ & $\begin{array}{l}.81 \\
.67\end{array}$ & $"$ \\
\hline $\begin{array}{l}113 \\
112\end{array}$ & $\begin{array}{r}6 \\
12\end{array}$ & $\begin{array}{l}1.6 \\
1.6\end{array}$ & $\begin{array}{r}.95 \\
1.95\end{array}$ & $\begin{array}{l}6 \cdot 3 \\
6.54\end{array}$ & $\begin{array}{l}1.03 \\
1.97\end{array}$ & $\begin{array}{l}7 \cdot 45 \\
6 \cdot 8\end{array}$ & $\begin{array}{l}3 \cdot 6 \\
3 \cdot 28\end{array}$ & $\begin{array}{l}6 \cdot 39 \\
5 \cdot 83\end{array}$ & $\begin{array}{l}\cdot 67 \\
.63\end{array}$ & $"$ \\
\hline $\begin{array}{l}2214 \\
1411\end{array}$ & $\begin{array}{l}11 \cdot 2 \\
12\end{array}$ & $\begin{array}{c}\cdot 8 \\
1 \cdot 62\end{array}$ & $\begin{array}{l}1 \cdot 57 \\
1 \cdot 62\end{array}$ & $\begin{array}{l}7 \cdot 14 \\
7 \cdot 4\end{array}$ & $\begin{array}{r}\cdot 67 \\
1 \cdot 15\end{array}$ & $\begin{array}{l}6 \cdot 75 \\
5 \cdot 85\end{array}$ & $\begin{array}{l}3 \cdot 25 \\
2 \cdot 82\end{array}$ & $\begin{array}{l}5 \cdot 79 \\
5 \cdot 01\end{array}$ & $\begin{array}{l}\cdot 53 \\
\cdot 45\end{array}$ & $"$ \\
\hline 111 & 12 & $1 \cdot 6$ & .95 & $12 \cdot 6$ & -48 & $7 \cdot 00$ & $3 \cdot 37$ & 6.00 & $\cdot 32$ & $"$ \\
\hline $\begin{array}{l}2221 \\
1231\end{array}$ & $\begin{array}{l}3 \cdot 6 \\
5\end{array}$ & $\begin{array}{l}1 \cdot 6 \\
1 \cdot 0\end{array}$ & $\begin{array}{l}1 \cdot 2 \\
1 \cdot 6\end{array}$ & $\begin{array}{l}3 \cdot 0 \\
3 \cdot 15\end{array}$ & $\begin{array}{l}1 \cdot 85 \\
1 \cdot 74\end{array}$ & $\begin{array}{l}\mathbf{5} \cdot 08 \\
\mathbf{5} \cdot 95\end{array}$ & $\begin{array}{l}2 \cdot 45 \\
2 \cdot 87\end{array}$ & $\begin{array}{l}4 \cdot 36 \\
5 \cdot 10\end{array}$ & $\begin{array}{r}.96 \\
1.09\end{array}$ & $\begin{array}{c}\text { Tan- } \\
\text { gential. }\end{array}$ \\
\hline $\begin{array}{l}1232 \\
1412\end{array}$ & $\begin{array}{l}6 \\
6\end{array}$ & $\begin{array}{l}1 \cdot 0 \\
1 \cdot 62\end{array}$ & $\begin{array}{l}1 \cdot 6 \\
1 \cdot 62\end{array}$ & $\begin{array}{l}3 \cdot 75 \\
3 \cdot 75\end{array}$ & $\begin{array}{l}1 \cdot 67 \\
2 \cdot 43\end{array}$ & $\begin{array}{l}6 \cdot 85 \\
6 \cdot 15\end{array}$ & $\begin{array}{l}3 \cdot 3 \\
2 \cdot 96\end{array}$ & $\begin{array}{l}5 \cdot 87 \\
5 \cdot 27\end{array}$ & $\begin{array}{r}1 \cdot 05 \\
\cdot 94\end{array}$ & 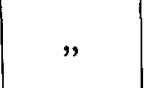 \\
\hline $\begin{array}{r}332 \\
1233\end{array}$ & $\begin{array}{r}12 \\
7\end{array}$ & $\begin{array}{l}1 \cdot 45 \\
1 \cdot 0\end{array}$ & $\begin{array}{l}3 \cdot 1 \\
1 \cdot 6\end{array}$ & $\begin{array}{l}3 \cdot 86 \\
4 \cdot 4\end{array}$ & $\begin{array}{l}3.98 \\
165\end{array}$ & $\begin{array}{l}6.0 \\
7.9\end{array}$ & $\begin{array}{l}2 \cdot 9 \\
3 \cdot 81\end{array}$ & $\begin{array}{l}5 \cdot 15 \\
6 \cdot 78\end{array}$ & $\begin{array}{r}88 \\
1.03\end{array}$ & $"$ \\
\hline $\begin{array}{l}2222 \\
1414\end{array}$ & $\begin{array}{l}4 \cdot 8 \\
7\end{array}$ & $\begin{array}{l}1 \cdot 6 \\
1 \cdot 62\end{array}$ & $\begin{array}{l}1 \cdot 2 \\
1 \cdot 62\end{array}$ & $\begin{array}{l}4 \cdot 0 \\
4 \cdot 35\end{array}$ & $\begin{array}{l}1 \cdot 75 \\
2 \cdot 11\end{array}$ & $\begin{array}{l}6 \cdot 38 \\
6 \cdot 5\end{array}$ & $\begin{array}{l}3 \cdot 08 \\
3 \cdot 14\end{array}$ & $\begin{array}{l}5 \cdot 47 \\
5 \cdot 57\end{array}$ & $\begin{array}{l}\cdot 91 \\
\cdot 80\end{array}$ & •" \\
\hline $\begin{array}{l}2223 \\
1234\end{array}$ & $\begin{array}{l}6 \\
8\end{array}$ & $\begin{array}{l}1 \cdot 6 \\
1 \cdot 0\end{array}$ & $\begin{array}{l}1 \cdot 2 \\
1 \cdot 6\end{array}$ & $\begin{array}{l}5 \cdot 0 \\
5 \cdot 0\end{array}$ & $\begin{array}{l}1 \cdot 75 \\
1 \cdot 26\end{array}$ & $\begin{array}{l}7 \cdot 95 \\
6 \cdot 92\end{array}$ & $\begin{array}{l}3 \cdot 84 \\
3 \cdot 35\end{array}$ & $\begin{array}{l}6 \cdot 81 \\
5 \cdot 93\end{array}$ & $\begin{array}{r}\cdot 91 \\
\cdot 78\end{array}$ & $"$ \\
\hline $\begin{array}{l}2212 \\
1221\end{array}$ & $\begin{array}{l}4 \cdot 8 \\
9 \cdot 6\end{array}$ & $\begin{array}{r}1 \cdot 57 \\
\cdot 82\end{array}$ & $\begin{array}{c}\cdot 8 \\
1.57\end{array}$ & $\begin{array}{l}6 \cdot 0 \\
612\end{array}$ & $\begin{array}{r}1 \cdot 05 \\
\cdot 81\end{array}$ & $\begin{array}{l}8 \cdot 75 \\
6 \cdot 7\end{array}$ & $\begin{array}{l}4 \cdot 22 \\
3 \cdot 24\end{array}$ & $\begin{array}{l}7 \cdot 50 \\
5 \cdot 74\end{array}$ & $\begin{array}{l}\cdot 83 \\
\cdot 62\end{array}$ & $"$ \\
\hline $\begin{array}{l}2213 \\
1224\end{array}$ & $\begin{array}{r}5 \cdot 6 \\
112\end{array}$ & $\begin{array}{r}1 \cdot 57 \\
\cdot 82\end{array}$ & $\begin{array}{c}\cdot 8 \\
1 \cdot 57\end{array}$ & $\begin{array}{l}7 \\
7 \cdot 14\end{array}$ & $\begin{array}{l}\cdot 84 \\
\cdot 75\end{array}$ & $\begin{array}{l}8 \cdot 05 \\
7 \cdot 25\end{array}$ & $\begin{array}{l}\mathbf{3} \cdot 88 \\
\mathbf{3} \cdot \mathbf{5}\end{array}$ & $\begin{array}{l}7 \cdot 90 \\
6 \cdot 21\end{array}$ & $\begin{array}{r}\cdot 66 \\
\cdot 58\end{array}$ & $"$ \\
\hline 1412 & 12 & $1 \cdot 62$ & $1 \cdot 62$ & $7 \cdot 4$ & $1 \cdot 45$ & $7 \cdot 15$ & $3 \cdot 45$ & $6 \cdot 13$ & $\cdot 55$ & $"$ \\
\hline
\end{tabular}


Ash.

\begin{tabular}{|c|c|c|c|c|c|c|c|c|c|c|}
\hline Spec. No. & Span. & $b$. & $d$. & $\frac{\mathrm{I}_{4}}{\dot{d}}$ & $\begin{array}{l}\text { Breaking } \\
\text { Load in } \\
\text { Tons. }\end{array}$ & $\begin{array}{c}t=\frac{2 \cdot 35 \mathrm{WL}}{b d^{2}} . \\
\text { Tons } \\
\text { per sq. in. }\end{array}$ & $\begin{array}{c}c=\frac{.75 \mathrm{WL}}{b d^{2}} . \\
\text { Tons } \\
\text { per sq. in. }\end{array}$ & $\begin{array}{l}\begin{array}{l}\text { Elastic } \\
\text { Formula, } \\
t=c=1 \cdot 5 \cdot \frac{\mathrm{W} \mathrm{L}}{b d^{2}}\end{array}\end{array}$ & $\begin{array}{c}\mathbf{S}={ }_{b d}^{\mathrm{W}} \\
\text { 'lons } \\
\text { per sq. in. }\end{array}$ & $\begin{array}{c}\text { Horizontal } \\
\text { Shear. }\end{array}$ \\
\hline 121 & 18 & $1: 85$ & $3 \cdot 45$ & $5 \cdot 2$ & $4 \cdot 7$ & 9.05 & $2 \cdot 88$ & $5 \cdot 76$ & .731 & Kadial. \\
\hline 431 & 8 & $3 \cdot 5$ & $1 \cdot 32$ & 6 & $3 \cdot 11$ & $9 \cdot 6$ & $3 \cdot 06$ & $6 \cdot 12$ & $\cdot 67$ & , \\
\hline 432 & 9 & $3 \cdot 5$ & 1.32 & $6 \cdot 8$ & $3 \cdot 03$ & 10.5 & $3 \cdot 35$ & $6 \cdot 70$ & .66 & , \\
\hline 211 & 14 & $3 \cdot 62$ & $1 \cdot 65$ & $8 \cdot 5$ & $2 \cdot 83$ & 9.5 & 3.03 & 6.06 & $\cdot 47$ & $"$ \\
\hline 122 & 36 & $1 \cdot 87$ & $3 \cdot 55$ & $10 \cdot 1$ & $2 \cdot 35$ & $8 \cdot 45$ & $2 \cdot 7$ & $5 \cdot 40$ & .36 & , \\
\hline 531 & 36 & $1 \cdot 77$ & $3 \cdot 52$ & $10 \cdot 2$ & $2 \cdot 18$ & $8 \cdot 45$ & $2 \cdot 7$ & $5 \cdot 40$ & .35 & , \\
\hline 212 & 18 & $3 \cdot 62$ & $1 \cdot 65$ & $10 \cdot 9$. & $2 \cdot 3$ & $9 \cdot 7$ & $3 \cdot 09$ & $6 \cdot 18$ & .38 & "? \\
\hline 41 & 36 & $1 \cdot 6$ & $3 \cdot 2$ & $11 \cdot 3$ & $1 \cdot 59$ & $8 \cdot 25$ & $2 \cdot 63$ & $5 \cdot 26$ & 31 & " \\
\hline 33 & 36 & $3 \cdot 62$ & $1 \cdot 65$ & $21 \cdot 8$ & .98 & $8 \cdot 45$ & $2 \cdot 7$ & $5 \cdot 4$ & $\cdot 16$ & $"$ \\
\hline 123 & 9 & $3 \cdot 45$ & $1 \cdot 85$ & $4 \cdot 85$ & $5 \cdot 2$ & $9 \cdot 3$ & $2 \cdot 96$ & 5.92 & $\cdot 83$ & Tan- \\
\hline 433 & 21 & $1 \cdot 32$ & $3 \cdot 5$ & 6 & $2 \cdot 92$ & $8 \cdot 9$ & $2 \cdot 84$ & $5 \cdot 68$ & .63 & gential. \\
\hline 532 & 14 & $3 \cdot 52$ & $1 \cdot 77$ & $7 \cdot 9$ & $3 \cdot 25$ & $9 \cdot 7$ & $3 \cdot 09$ & $6 \cdot 18$ & .52 &, \\
\hline 533 & 18 & $3 \cdot 52$ & $1 \cdot 77$ & $10 \cdot 1$ & $2 \cdot 06$ & $7 \cdot 9$ & 2.52 & $5 \cdot 04$ & $\cdot 33$ & $"$ \\
\hline 213 & 36 & $1 \cdot 65$ & $3 \cdot 62$ & 9.95 & $2 \cdot 22$ & $8 \cdot 7$ & $2 \cdot 78$ & $5 \cdot 56$ & 37 & $"$ \\
\hline 434 & 36 & $1 \cdot 32$ & $3 \cdot 5$ & $10 \cdot 3$ & $1 \cdot 77$ & $9 \cdot 25$ & $2 \cdot 95$ & $5 \cdot 70$ & $\cdot 38$ & $"$ \\
\hline 15 & 36 & $1 \cdot 65$ & $3 \cdot 6$ & 10 & $2 \cdot 13$ & 8.35 & $2 \cdot 66$ & 532 & $\cdot 36$ & $"$ \\
\hline 31 & 36 & $3 \cdot 63$ & $1 \cdot 65$ & $21 \cdot 8$ & $1 \cdot 13$ & $9 \cdot 7$ & 3.09 & $6 \cdot 18$ & $\cdot 19$ & $"$ \\
\hline
\end{tabular}

BoxwooD.

\begin{tabular}{|c|c|c|c|c|c|c|c|c|c|c|}
\hline Spec. No. & Span. & b. & $d$. & $\frac{\mathrm{L}}{d}$. & $\begin{array}{l}\text { Breaking } \\
\text { Load in } \\
\text { Tons. }\end{array}$ & $t=\frac{1.94 \mathrm{WL}}{b d^{2}}$. & $c=\frac{\mathbf{8 2 W L}}{b d^{2}}$. & $\begin{array}{l}\begin{array}{l}\text { Elastic } \\
\text { Formula, }\end{array} \\
t=c=1 \cdot 5 \frac{\mathrm{WL}}{b d^{2}}\end{array}$ & $\begin{array}{l}\mathrm{S}=\frac{\mathrm{W}}{b d} . \\
\text { Tons. }\end{array}$ & $\begin{array}{l}\text { Horizontal } \\
\text { Shear. }\end{array}$ \\
\hline 71 & $\ddot{5} \cdot 6$ & $1 \cdot 7$ & 1.4 & 4 & $2 \cdot 66$ & $8 \cdot 7$ & 3.67 & 674 & $1 \cdot 12$ & Rudial. \\
\hline 111 & 8 & 1.05 & 2 & 4 & 1.98 & $7 \cdot 3$ & 3.08 & $5 \cdot 67$ & .94 & - \\
\hline 112 & 12 & 1.05 & 2 & 6 & $1 \cdot 49$ & $8 \cdot 25$ & $3 \cdot 48$ & $6 \cdot 40$ & $\cdot 71$ & " \\
\hline 72 & $8 \cdot 4$ & $1 \cdot 7$ & $1 \cdot 4$ & 6 & 1.95 & $9 \cdot 55$ & $4 \cdot 04$ & $7 \cdot 40$ & $\cdot 82$ & " \\
\hline 73 & 14 & 2 & $1 \cdot 4$ & 10 & $\cdot 78$ & $5 \cdot 5$ & $2 \cdot 32$ & $4 \cdot 25$ & $\cdot 28$ & ", \\
\hline 113 & 20 & $1 \cdot 05$ & 2 & 10 & $I \cdot 15$ & $10 \cdot 6$ & $4 \cdot 48$ & $8 \cdot 23$ & .55 & , \\
\hline 4 & 36 & $1 \cdot 18$ & $2 \cdot 08$ & $17 \cdot 3$ & .63 & $8 \cdot 6$ & $3 \cdot 64$ & $6 \cdot 68$ & -26 & $"$ \\
\hline 114 & 4 & 2 & $1 \cdot 05$ & $3 \cdot 8$ & 3.06 & $10 \cdot 7$ & $4 \cdot 52$ & $8 \cdot 29$ & $1 * 46$ & Tan- \\
\hline 74 & $6 \cdot 8$ & $1 \cdot 4$ & $1 \cdot 7$ & 4 & $2 \cdot 86$ & $9 \cdot 35$ & 3.95 & $7 \cdot 25$ & $1 \cdot 2$ & gential. \\
\hline 115 & 6 & 2 & 1.05 & $5 \cdot 7$ & $2 \cdot 26$ & $11 \cdot 9$ & $5 \cdot 05$ & $9 \cdot 28$ & 1.07 & , \\
\hline 75 & $10 \cdot 2$ & $1 \cdot 4$ & $1 \cdot 7$ & 6 & $1 \cdot 03$ & $5 \cdot 05$ & $2 \cdot 14$ & $3 \cdot 93$ & $\cdot 43$ & ," \\
\hline 76 & 20 & $1 \cdot 4$ & $2 \cdot 0$ & 10 & $1 \cdot 55$ & $10 \cdot 4$ & $4 \cdot 4$ & 8.08 & .55 & , \\
\hline 10 & 36 & $1 \cdot 14$ & $2 \cdot 32$ & $15 \cdot 5$ & $\cdot 7$ & $8 \cdot 0$ & $3 \cdot 37$ & $6 \cdot 18$ & $\cdot 26$ & $"$ \\
\hline
\end{tabular}

Taking the average values in each set of tests, we have :-

\begin{tabular}{|c|c|c|c|}
\hline $\begin{array}{c}\text { When } \\
\text { Horizontal Shear } \\
\text { is }\end{array}$ & $O_{\Delta K}$. & Ash. & BoxwooD. \\
\hline $\begin{array}{l}\text { Tangential } \\
\text { Radial }\end{array}$ & $\begin{array}{l}t=6 \cdot 88 \\
t=6 \cdot 25\end{array}$ & $\begin{array}{l}9 \cdot 0 \\
9 \cdot 1\end{array}$ & $\begin{array}{l}9 \cdot 2 \text { tons } \\
8 \cdot 4 \quad \text { ", }\end{array}$ \\
\hline $\begin{array}{l}\text { Tangential } \\
\text { Radial }\end{array}$ & $\begin{array}{l}s=.84 \\
s=\cdot 78\end{array}$ & $\begin{array}{l}\cdot 45 \\
\cdot 45\end{array}$ & $\begin{array}{l}.83 \text { tons } \\
.67\end{array}$ \\
\hline
\end{tabular}


This goes to show that a beam is rather stronger when laid with the medullary rays in a vertical plane and its annual rings as nearly as possible horizontal. This is in keeping with the results arrived at in ordinary shear, which showed that the timber

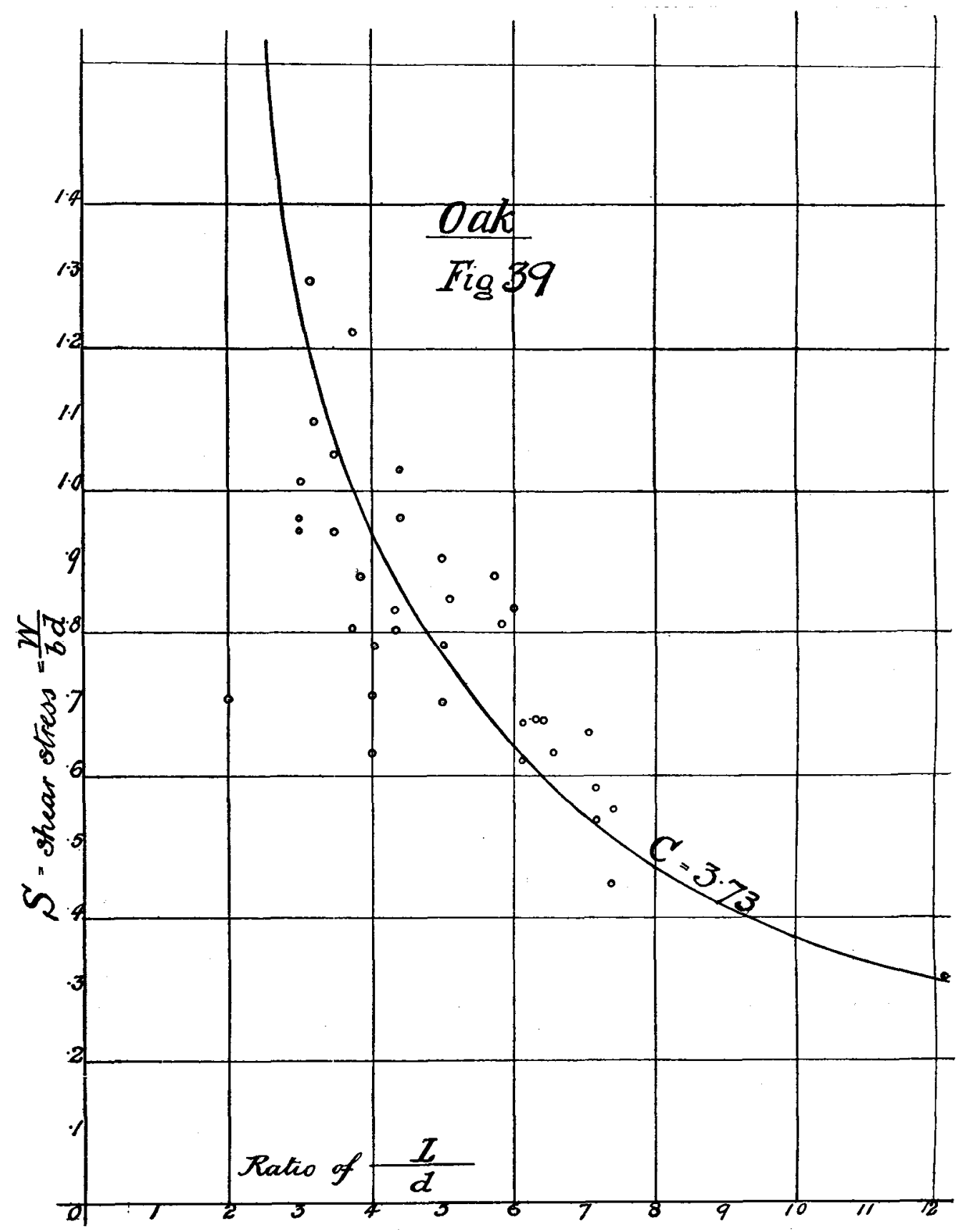

was better able to resist tangential shear than horizontal; but the difference, especially in the case of Ash, is not a very important one.

The values of the tensile and compressive stresses, as given in the above tables, 
show that the assumptions upon which the formula is based are approximately correct. This is illustrated if the shear values $s=\frac{W}{b \bar{d}}$ are plotted on a diagram as ordinates with the ratios of $\frac{L}{d}$ as abscissæ, as has been done in fig. 39. A fair curve to pass through the mean of these points is a hyperbola with a constant which, in the case of Oak, is equal to $3 \cdot 73$.

Thus

$$
\frac{\mathrm{W}}{b d} \cdot \frac{\mathrm{L}}{d}=\mathrm{C}=3 \cdot 73=\frac{t(\text { maximum tensile stress })}{k(\text { constant })}
$$

If the average value of $t$ is inserted here, say 6.53 tons, then

$$
k=\frac{6 \cdot 53}{373}=1 \cdot 75,
$$

which was the value of the calculated constant on the assumption of an approximately rectangular stress diagram.

It is difficult to account for the very high values which are apparently reached in some cases by the shear stresses; though the average values are in practical agreement with those in direct shear. The cases in which this excessive calculated value is reached occur only when the span is very short relative to the depth, and where, consequently, the central load is not far removed from the line of the reaction. The material is thus subjected to a compressive bearing stress which tends to increase the value of the resistance of the material to horizontal shear. As the load becomes more remote from the reaction, this effect grows less, and is not observable at that ratio of length of span to depth of beam at which the material will give either by tension, compression, or shear. That there is some raising of the shear value is evidenced by shearing taking place habitually in beams at what may be called the normal shearing value when $\frac{L}{d}$ is near the critical ratio, as well as at the more inflated value when $\frac{\mathrm{L}}{d}$ is very small. Fig. 32 shows some typical shearing fractures of Oak, but these fractures never occur above the critical ratio. With horizontal shear tangential, 4 was the highest value of $\frac{\mathrm{L}}{d}$ attained when shear was the direct cause of failure, and with horizontal shear radial, 5 . The only condition under which so high a value of $\frac{L}{d}$ as 10 could be reached in a beam fractured by horizontal shear would be where a shake, situated near the neutral axis, already existed in the timber, which would, of course, offer little resistance to shear.

\section{Conclusions.}

1. The initial cause of fracture in timbers lies in the medullary rays.

2. Rectangular beams when laid on a tangential face are stiffer and have a higher fracture value than when on a radial face. 
3. Rectangular beams of unequal sides are stiffer but not materially stronger when laid on the broad side of the section.

4. When at the fracture point a rectangular stress diagram very slightly modified accurately represents the distribution of stress in a timber beam.

5. For timber struts where the ratio of length to sinaller dimension of cross-section does not exceed 12 to 15 , a modification of the usual column formula is necessary.

6. Fracture by shearing does not take place in timber beams of the commoner woods supported at two ends and loaded in the middle where the ratio of span to depth of beam exceeds, say, 7.

The microscopic sections, micro-photographs, and photographs were prepared by Mr George West, University College, Dundee, to whom the author is greatly indebted for his assistance. The cost of these photographs was defrayed by a grant from the Carnegie Trust, which is here gratefully acknowledged. Thanks are also due to several of the students in University College, Dundee, especially Mr J. A. HooD, for aid given in the experimental work, and to the Council of University College, for their very generous assistance.

\section{EXPLANATION OF PLATES.}

\section{Prate I.}

Fig. 2. A block of Oak cut with the broad longitudinal sides tangential, and arranged so as to exhibit one of these sides. $\times \frac{7}{8}$ n.s. The fibres are displaced tangentially, local buckling taking place in two planes, more or less equally inclined to the direction of pressure.

Fig. 3. A block of Ash cut with the broad longitudinal sides tangential, and arranged so as to exhibit one of these sides. $\times \frac{7}{8}$ n.s. It has been fractured by crushing in a longitudinal direction, and the buckling has taken place in a single plane. This is the general case.

Fig. 4. A block of Ash with the broad longitudinal sides radial, and arranged so as to exhibit one of these sides. $\times \frac{7}{8}$ n.s. The illustration shows that there is no movement in a radial direction.

Fig. 5. A block of Boxwood cut with its broad longitudinal sides tangential, and arranged to show one of these sides. $\times \frac{7}{8}$ n.s.

Fig. 6. A block of Boxwood cut with its broad longitudinal sides radial, and arranged to show one of these sides. $\times \frac{7}{8}$ n.s. The stress is longitudinal compression and the displacement is tangential, irrespective of the proportions of the cross-section.

\section{Plate II.}

Fig. 7. Oak wood. A normal radial section, $\times 176$ diams., showing a medullary ray $(m)$ crossing wood-fibres $(f)$, wood-parenchynia $(p)$, etc.

Fig. 8. Oak wood. A normal transverse section at the zone of demarcation between the autumn wood of one year and the spring wood of the next, $\times 240$ dians., showing two narrow medullary rays $(m)$, woodfibres $(f)$, etc.

Fig. 9. Oak wood. A normal transyerse section at the line of denarcation between two annual zones of growth. $\times 88$ diams. One large tracheide $(t)$ and a portion of another are shown. The size of this tracheide should be compared with that of Box.

Fig. 10. Oak wood. A normal tangential section, $\times \mathbf{2 4 0}$ diams., showing a portion of a broad medullary ray $(M)$, narrow rays $(m)$, wood-fibres $(f)$, wood-parenchyma $(p)$, ete. 
Fig. 11. Oak wood. A general view of a tangential section of fractured wood, $\times 20$ diams., showing that the fracture takes place more readily at the medullary rays $(m)$ than at the apparently weaker tracheæ $(t)$.

Fig. 12. Oak wood. A tangential section from a partially crushed block, $\times 176$ diams., showing that the fracture is caused by the wood-fibres separating from the medullary rays $(m)$.

\section{Plate III.}

Fig. 13. Ash. A normal transverse section, $\times 240$ diams. It shows portions of trachex $(t)$, medullary rays $(m)$, wood-fibres $(f)$, etc. Tracheides shown only about one-third the size of those of Oak.

Fig. 14. Box. A normal transverse section, $\times 240$ diams. It shows tracheæ $(t)$, medullary rays $(m)$, wood-fibres $(f)$, etc. The relative size of the trachex in these three different woods may now be compared.

Fig. 15. Ash. A normal tangential section, $\times 240$ diams., showing medullary rays $(m)$ and woodfibres $(f)$. The sinuous path of the wood-fibres making their way past the medullary rays is well shown.

Fig. 16. Ash. A tangential section, $\times 176$ diams., of a fractured specimen. It shows early stage in the crumpling of the fibres and their splitting from the medullary rays.

Fig. 17. Box. A normal tangential section, $\times 240$ diams. It shows tracheæ $(t)$, medullary rays $(m)$, wood-fibres $(f)$, etc. Most of the medullary ray cells are filled with starch.

Fig. 18. Box. A tangential section, $\times 176$ diams., of specimen that has been compressed. It also shows crumpling of the fibres and their splitting from the medullary rays.

\section{Plate IV.}

Fig. 19. Oak. A set of strips, $\times \frac{7}{8}$ n.s., that have been fractured by tension. (a) exhibiting its narrow side, and $(b)$ exhibiting its broad side, were both cut with their broad sides tangential; $(c)$ and $(d)$, similarly shown, were cut with their broad sides radial. $(b)$ and $(c)$ therefore show a tangential face, and the fracture is a ragged one. In $(a)$ and $(d)$, where a radial face is exposed, there is an abrupt break extending more or less straight across the face. This is due to little or no slip taking place between the annual rings or wood-fibres radially adjacent, but a considerable slip takes place between the medullary rays and the adjacent fibres.

Fig. 20. Box. Three strips, $\times \frac{1}{2} \frac{9}{0}$ n.s., that have been fractured by tension. $(a)$ and $(b)$ exhibit tangential, and $(c)$ radial, faces. The fracture runs through the wood to a considerable extent tangentially, but radially it is very abrupt.

\section{Plate V.}

Fig. 21. Ash. One strip, $\times \frac{4}{5}$ u.s., fractured by tension. It has been cut with broad sides tangential, and exhibits one of these sides showing usual ragged break.

Fig. 22. Oak. A tangential section, $\times 76$ diams., from a beam fractured by cross-breaking, on the tension side. It shows the separation of tissues takes place most readily between medullary rays and adjacent tissues.

Fig. 23. Box. A tangential section, $\times 176$ diams., from a strip broken by tension.

Fig. 24. Box. A tangential face of beam, $\times \frac{7}{8}$ n.s.

\section{Plate VI.}

Fig. 25. Oak. A tangential face, $\times \frac{7}{8}$ n.s., of a beam fractured by cross-breaking. The ragged break on tensional part similar to that obtained in direct tension.

Fig. 26. Oak. Radial face of beam fractured by cross-breaking, and showing abrupt break, $\times \frac{7}{8}$ n.s.

Fig. 27. Ash. A beam eut with the broad sides radial, and arranged to show one of these sides, $\times \frac{17}{20}$ n.s., after cross-breaking. Note the bulging on the upper side due to compression.

Fig. 28. Oak. Transverse sections of two blocks cut with the broad longitudinal sides tangential, $\times \frac{7}{8}$ n.s., and subjected to a tangential stress which is less in $(a)$ than in $(b)$. 


\section{Plate VII.}

Fig. 29. Oak. A tangential section from the compressed side of a beam, $\times 176$ diams., showing crumpling of the tissues. The direction of the induced compression $\mathrm{C}$ is shown by the arrow-heads.

Fig. 30. Oak. A tangential section from the fractured lower portion of a beam, $\times 176$ diams.

Fig. 31. Oak. A transverse section of $\log , \times \frac{7}{8}$ n.s., which has been fractured by longitudinal compression. The slip is essentially a tangential one. Note.-This specimen contains the centre of tree.

Fig. 32. Oak. A set of beams which have been laid on their tangential face and fractured by crossbreaking. The radial faces are exhibited $\times \frac{1}{3}$ n.s. Note.--The line of shear is always nearer the tension side. Ratios of $\frac{\mathrm{L}}{d}$ less than 4 .

\section{Plate VIII.}

Fig. 33. Oak. Seven specimens fractured by longitudinal compression, $\times \frac{1}{3}$ n.s. $\mathrm{K}=$ narrow dimension, and is radial. Local buckling takes place until $l=8 k$, and is tangential. Above this it is a compound of bending and local crumpling in oblique plane.

Fig. 34. Oak. Seven specimens fractured by longitudinal compression, $\times \frac{1}{3}$ n.s. $\mathrm{K}=$ narrow dimension, and is tangential. Local buckling occurs until $l=6 k$ and is tangential. Above this it is a compound of bending and buckling in a vertical plane. 
Trans. Roy. Soc. Edin ${ }^{r}$

Fulton: Experiments on Timber. - Plate I.

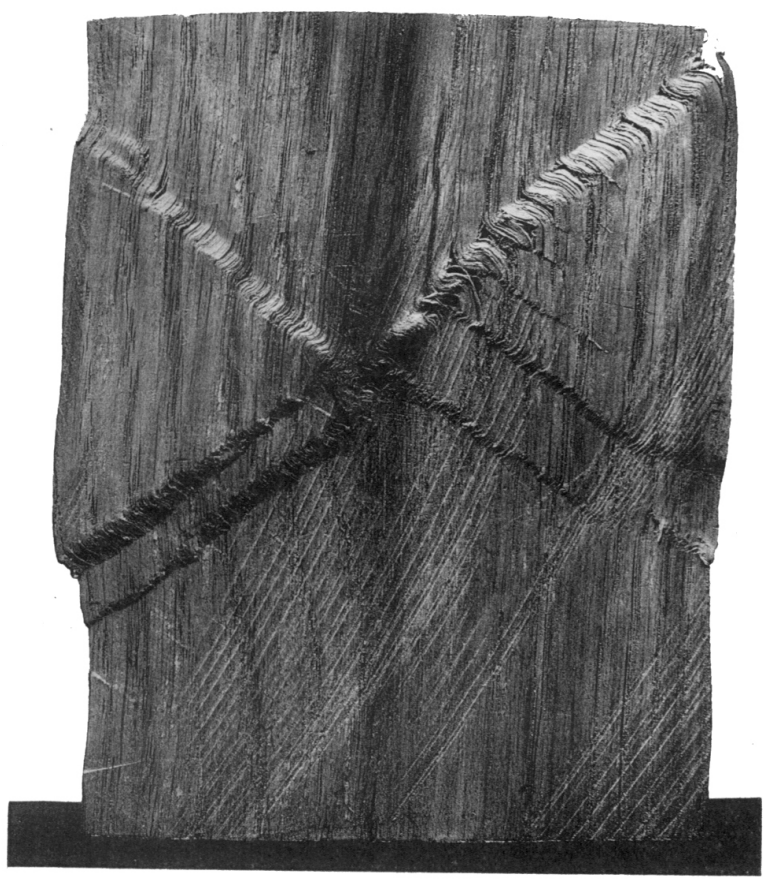

2

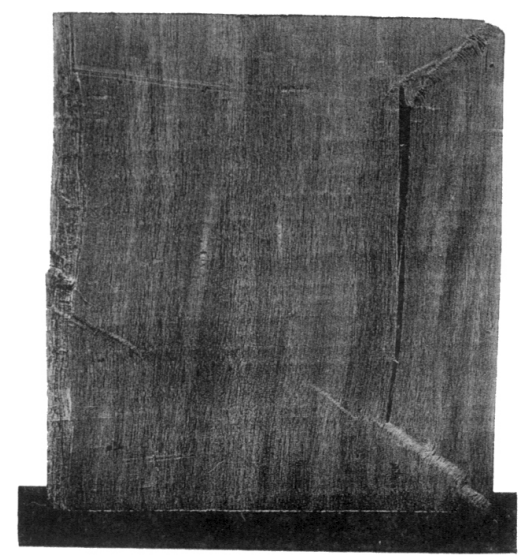

5

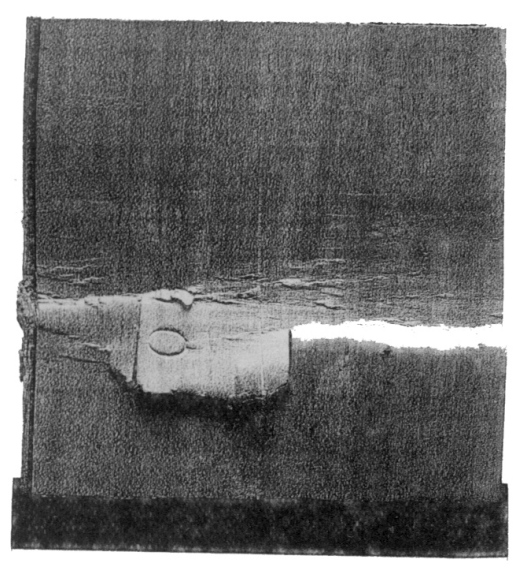

6

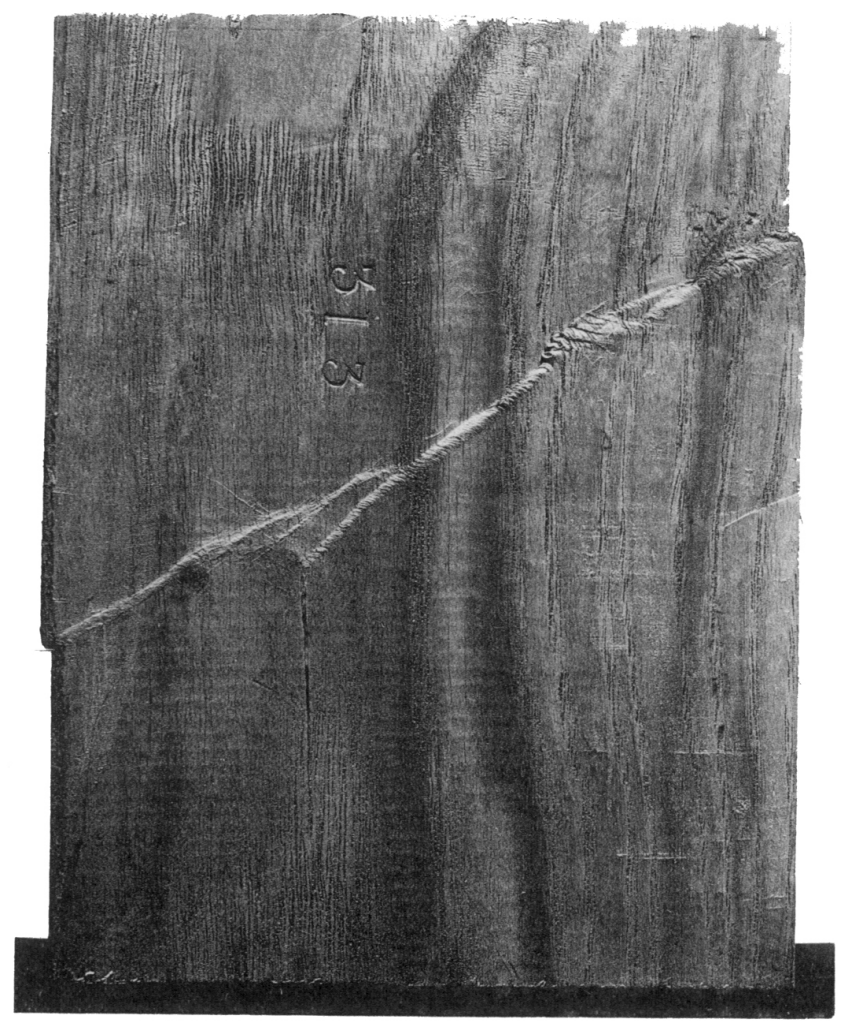

3

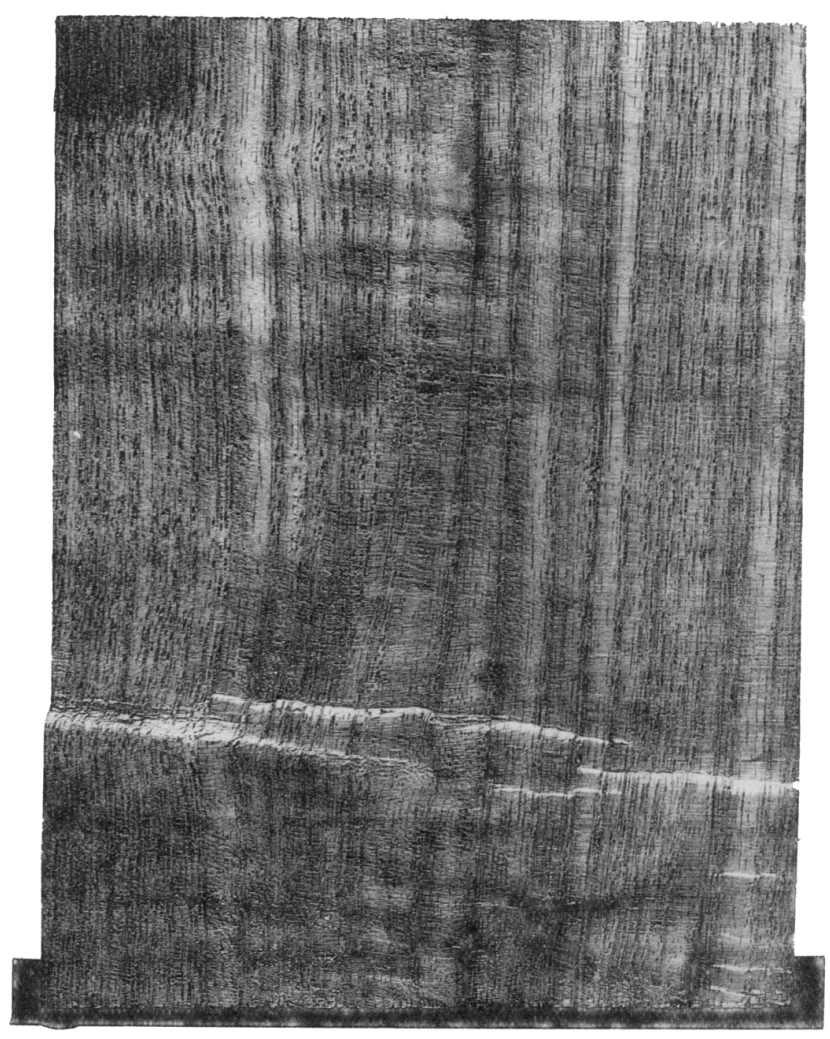

4 
Fulton: Experiments on Timber.-Plate II.
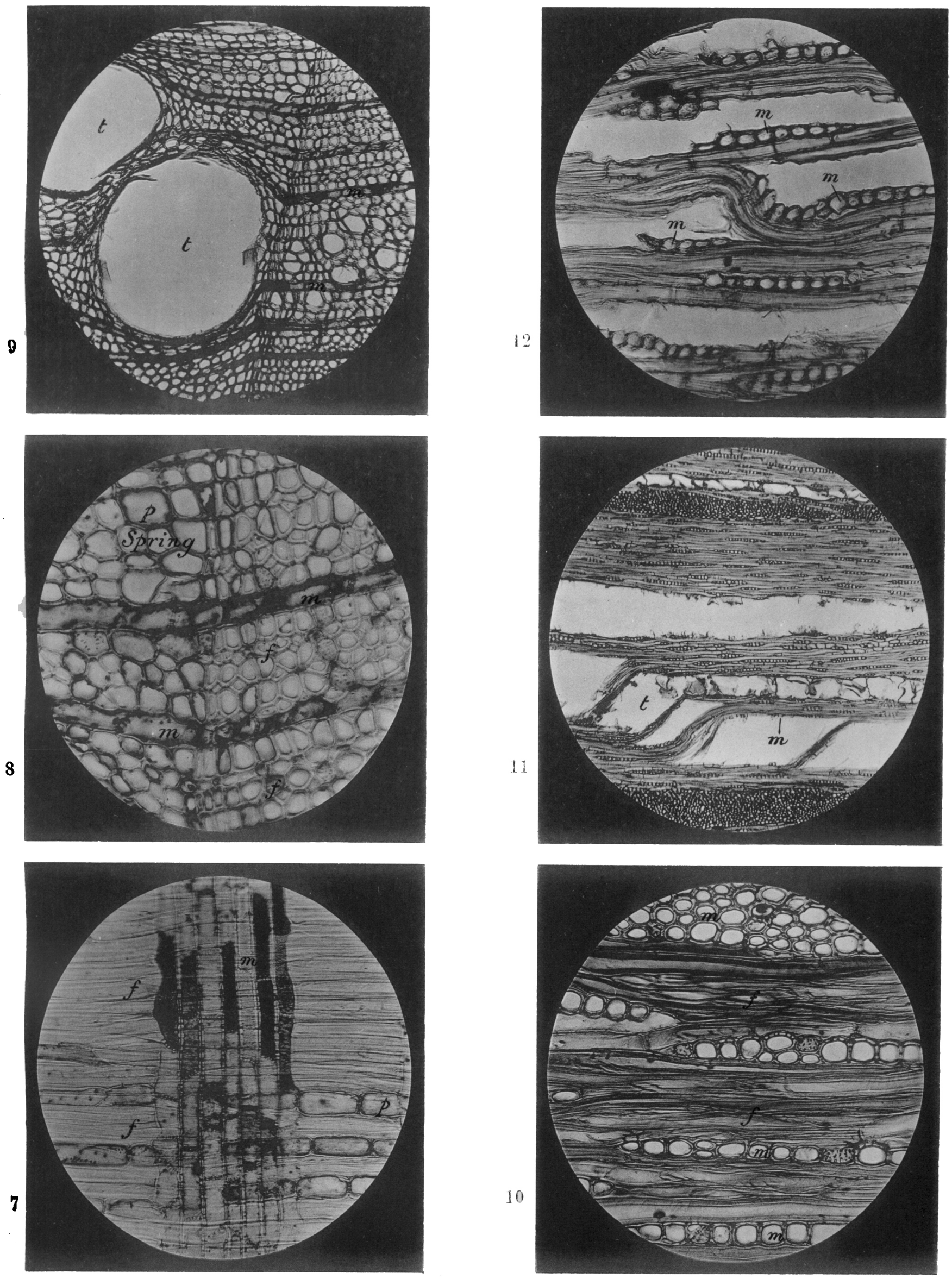
Fulton: Experiments on Timber. - Plate III.

15

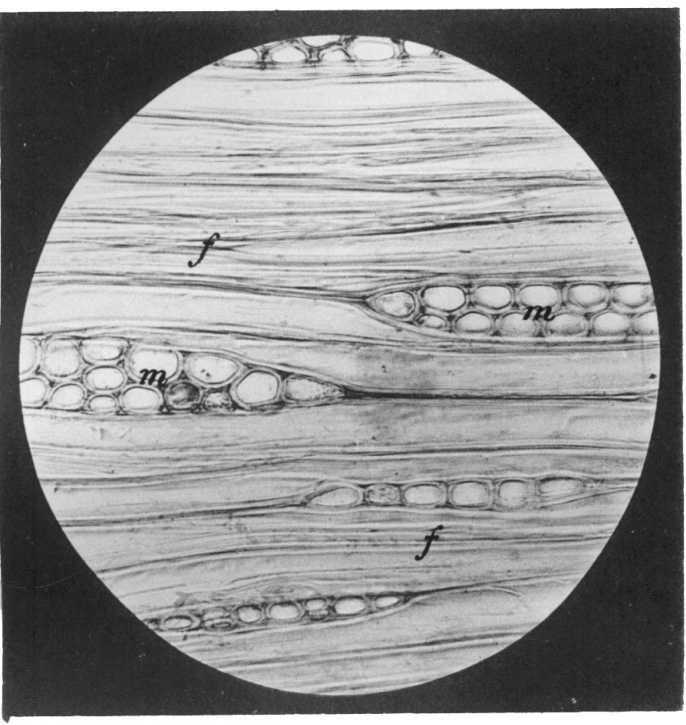

14

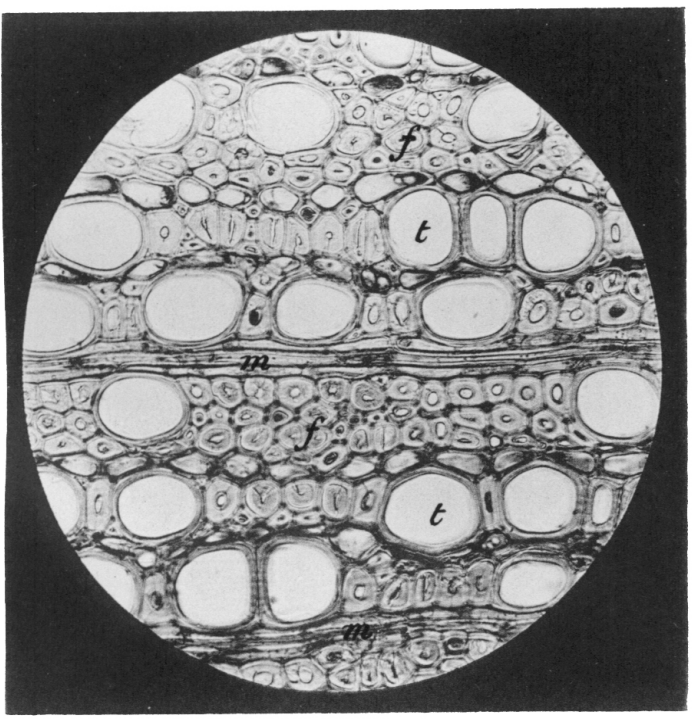

13

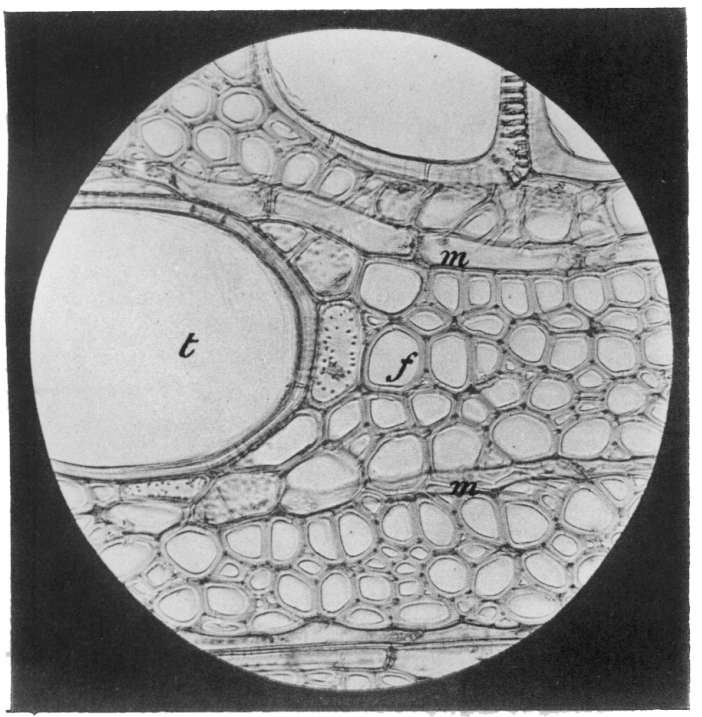

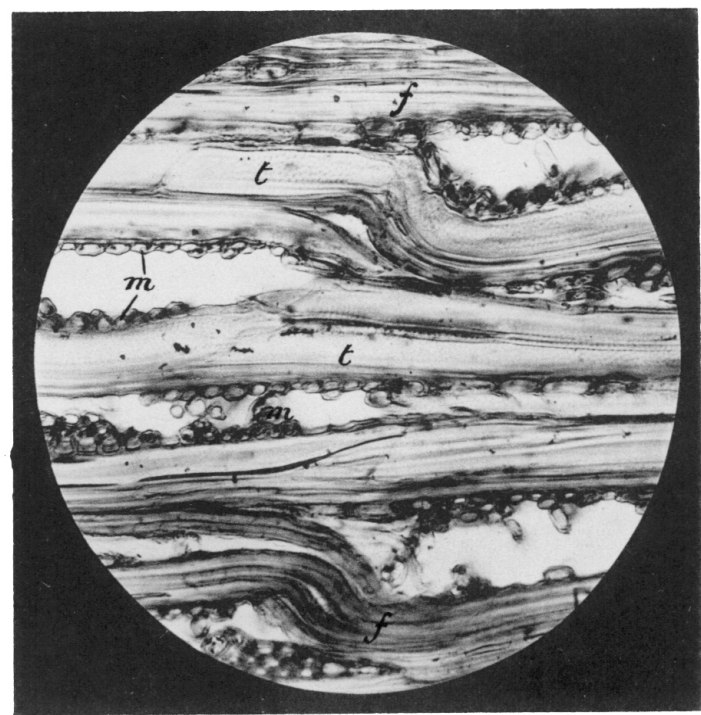

17
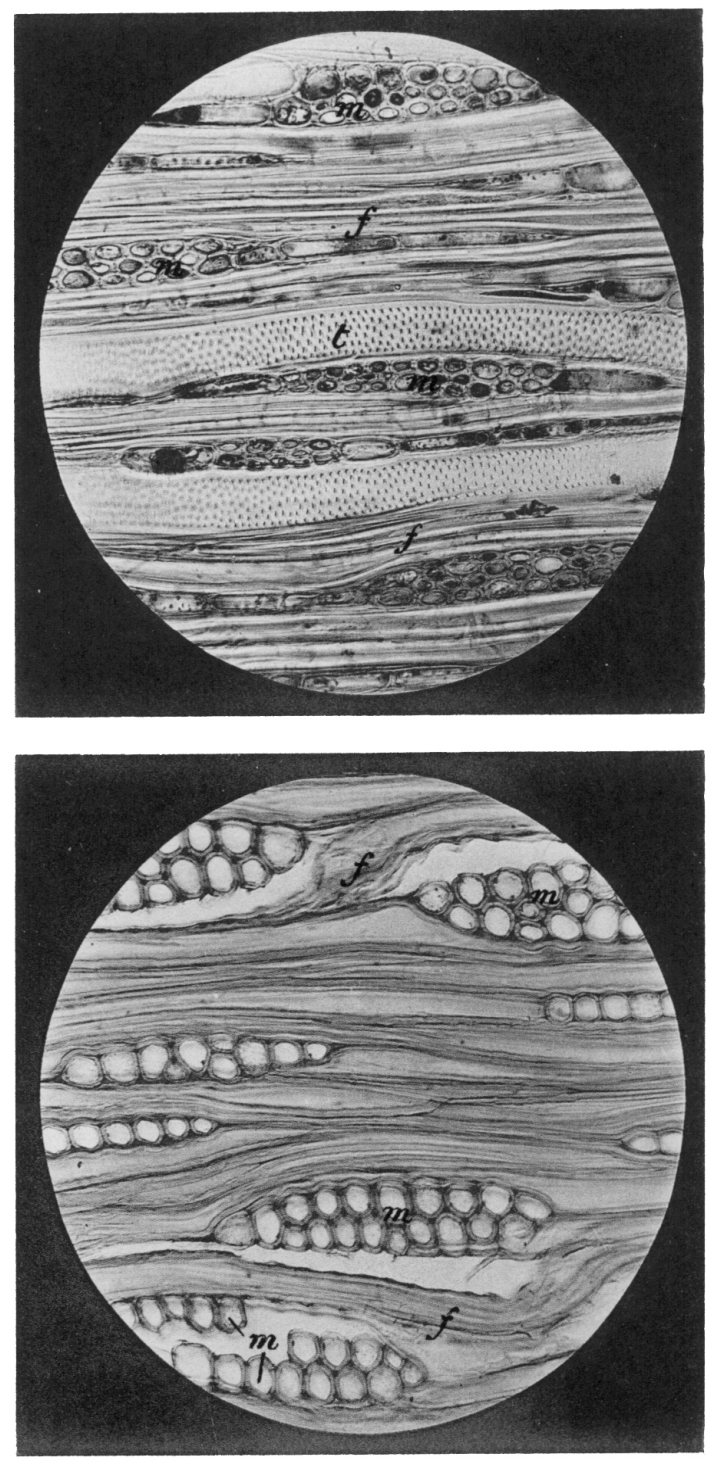
Fulton: Experiments on Timber. - Plate IV.

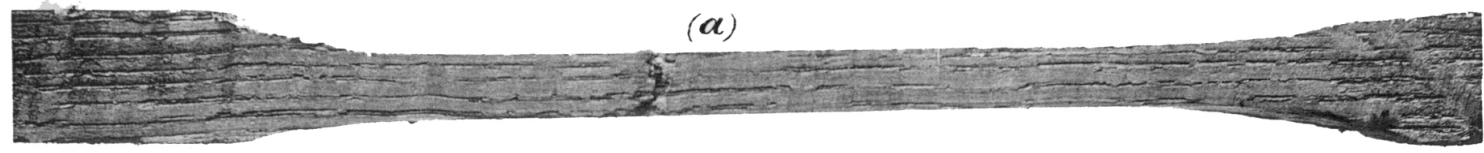

(b)
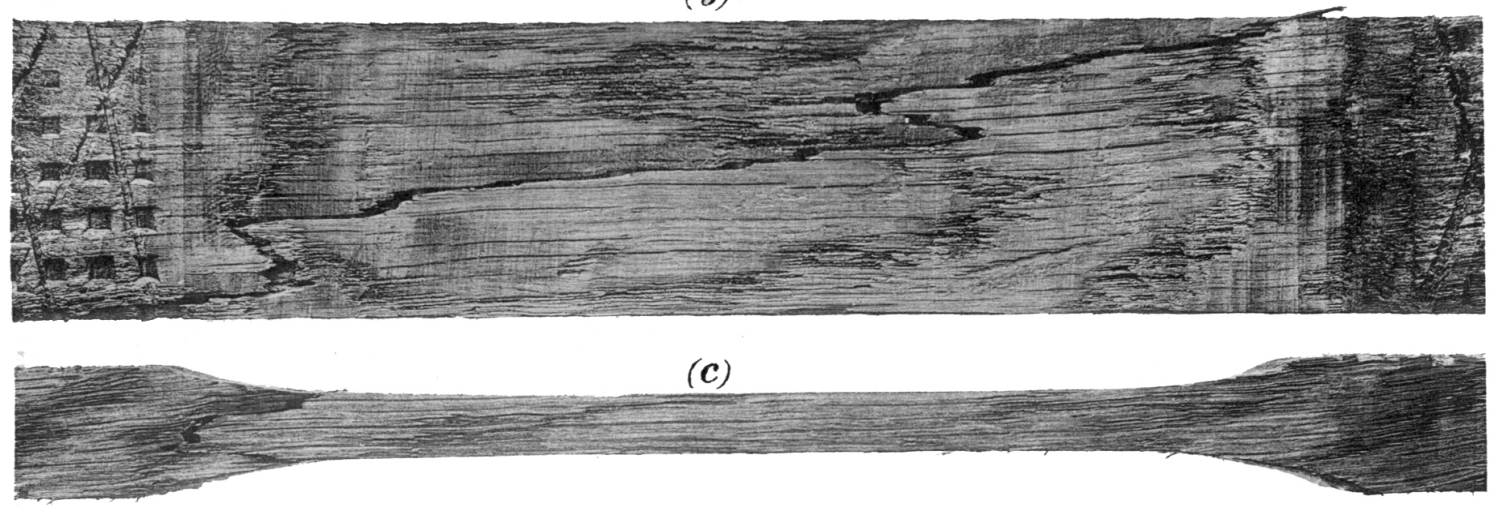

(d)

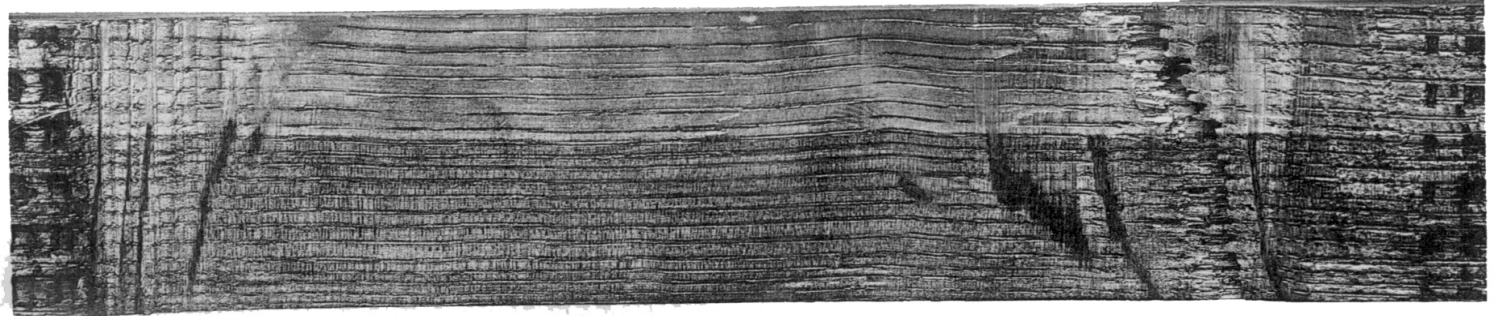

19

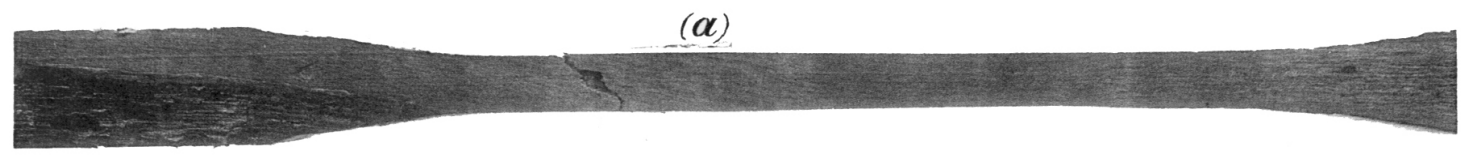

(b)

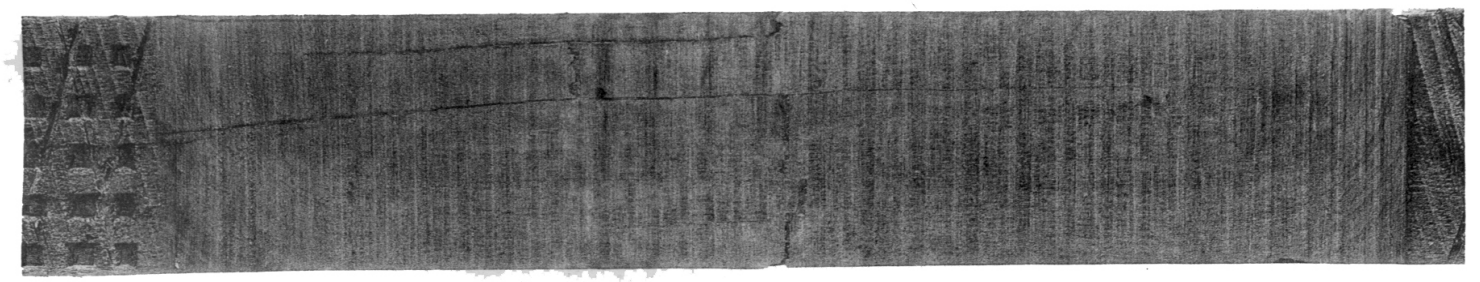

(c)

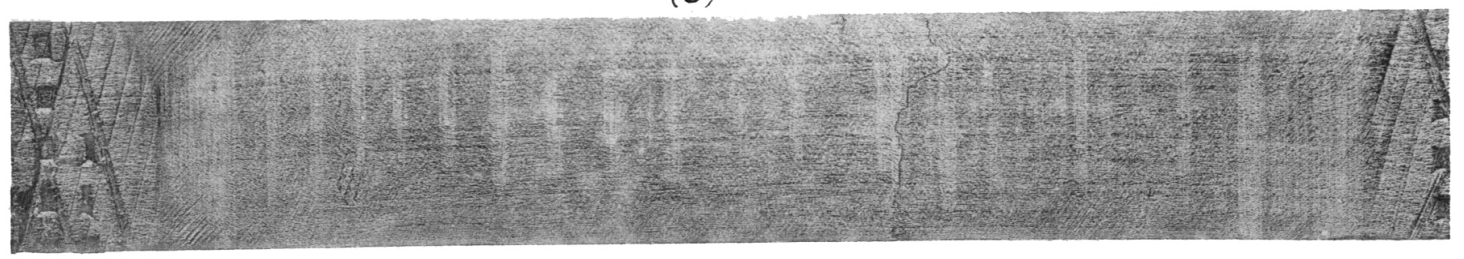


Trans. Roy. Soc. Edin

Fulton: Experiments on Timber -Plate V.

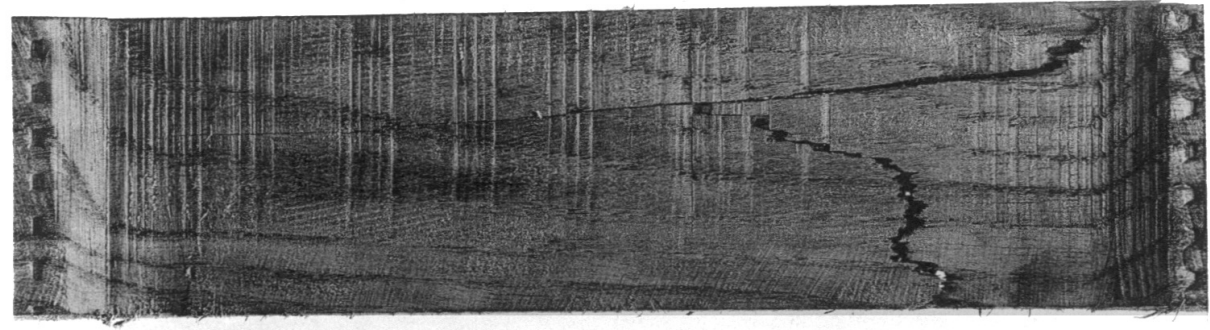

21

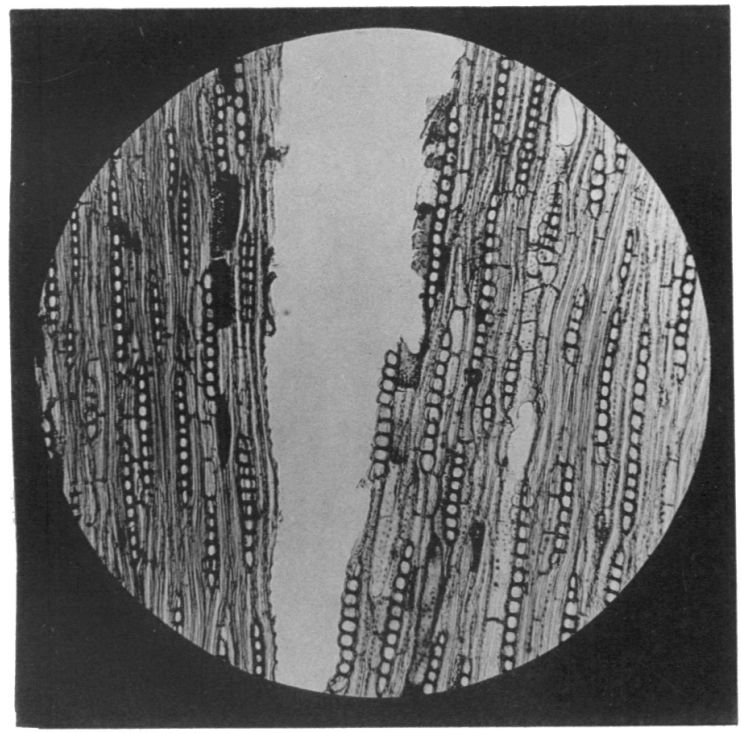

22

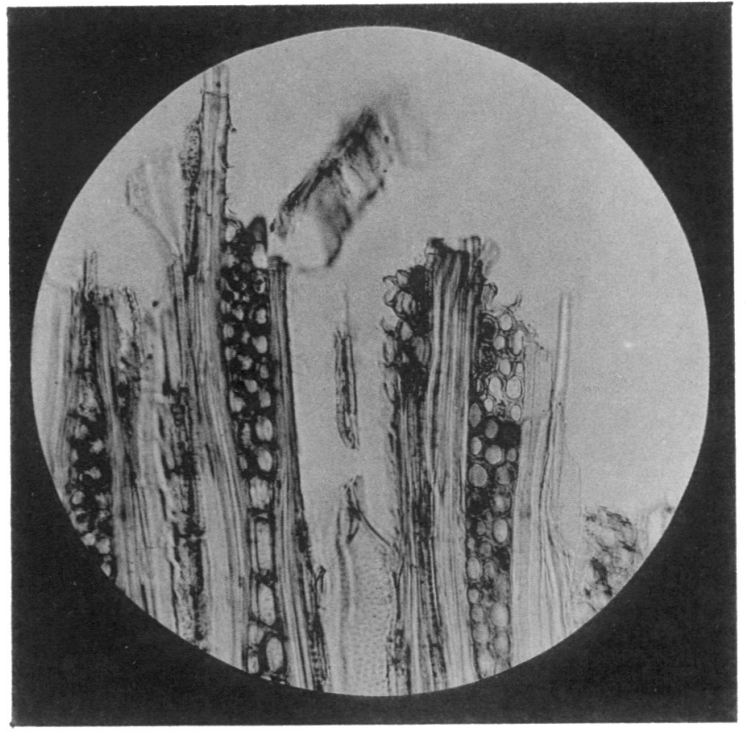

23

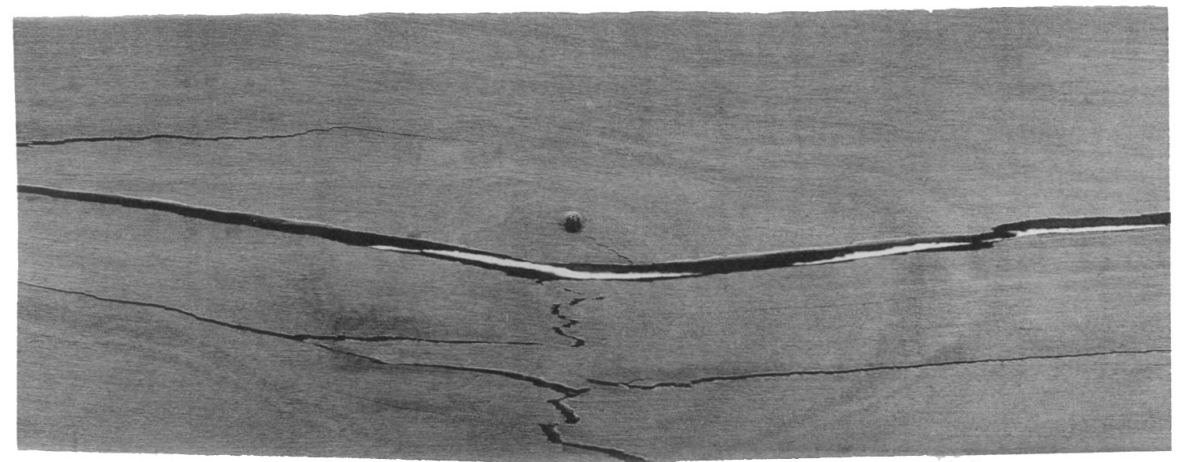


Fulton: Experiments on Timber.-Plate VI.

27

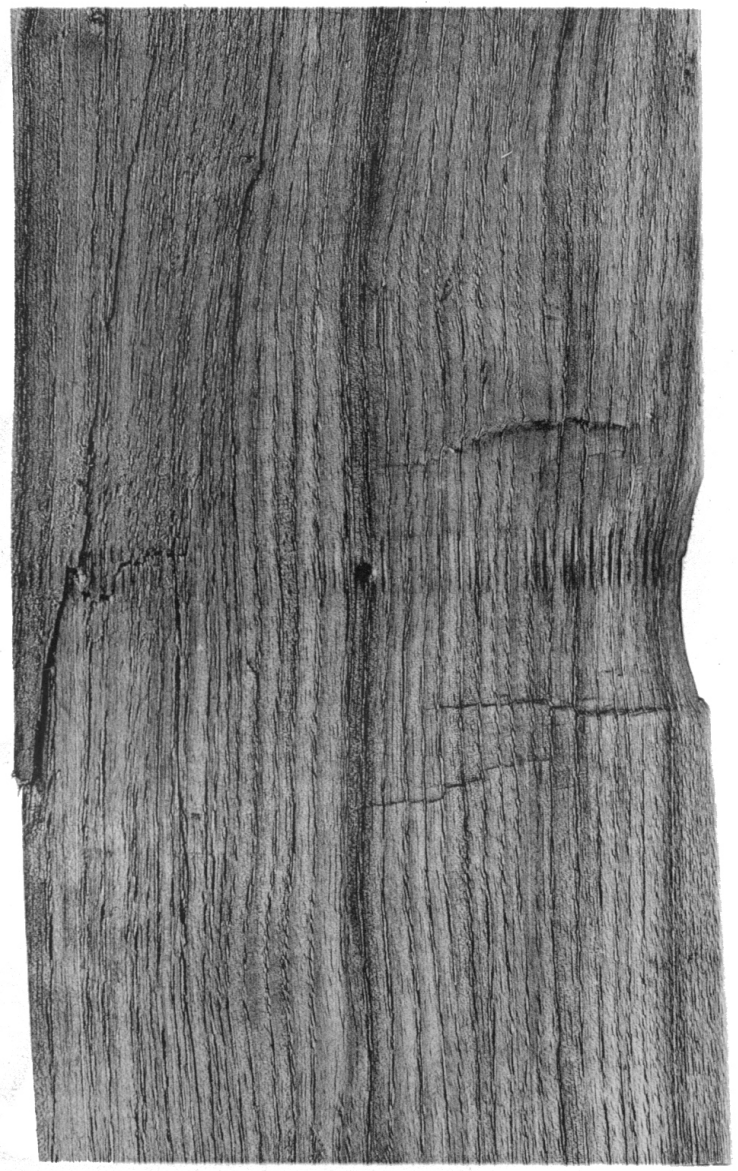

(a)

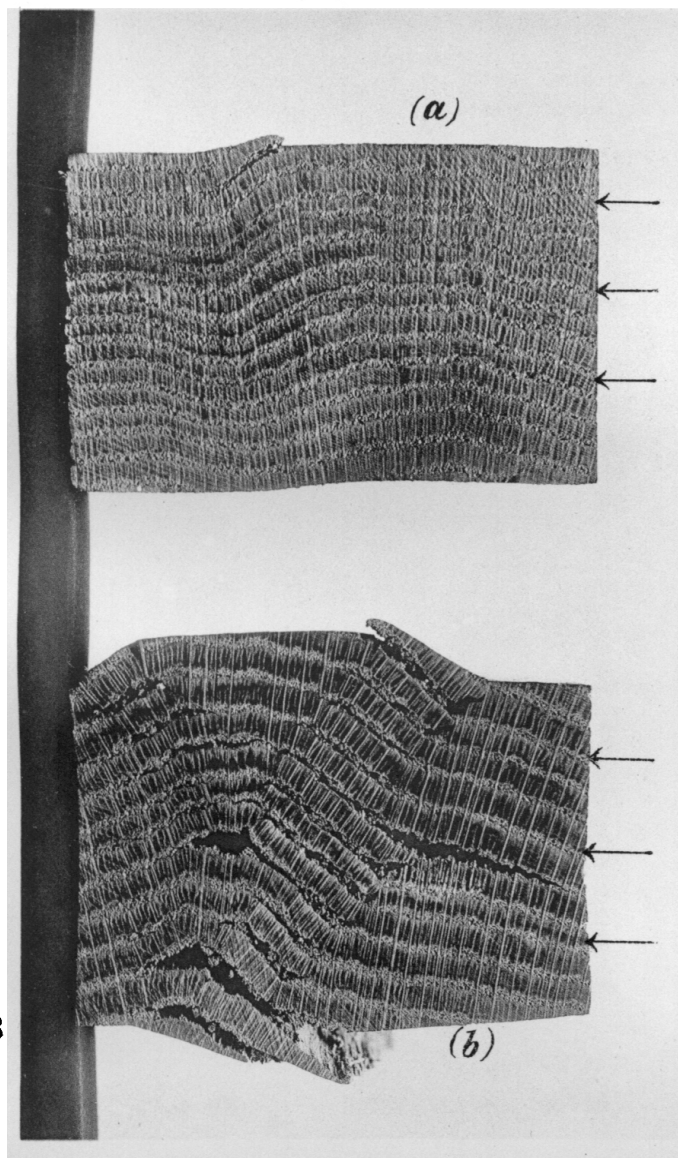

25
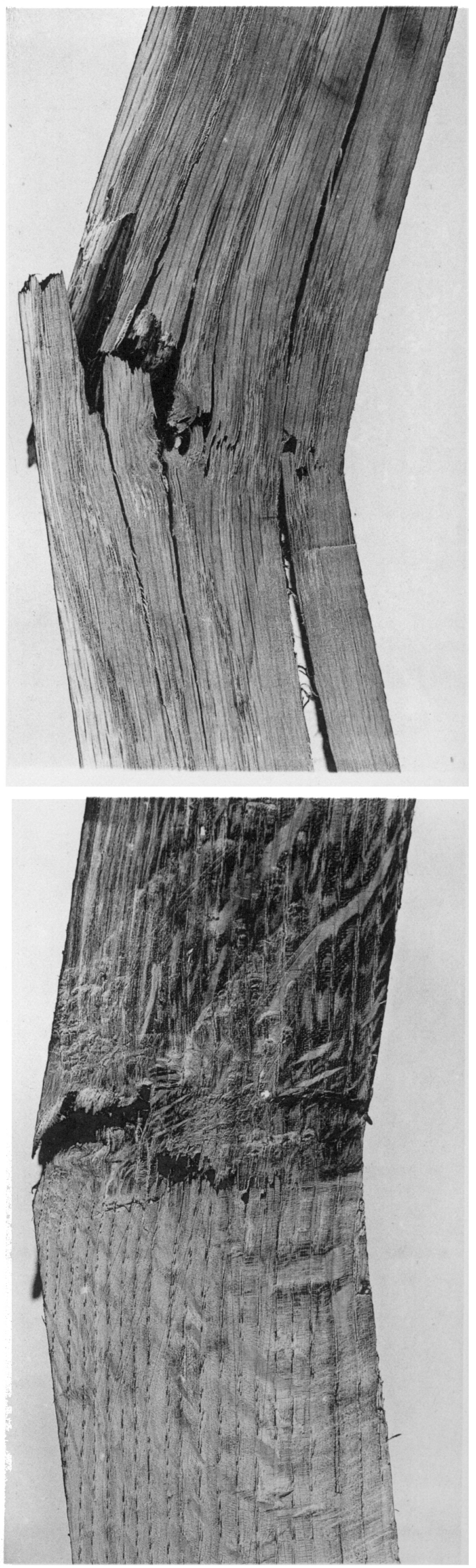
Fulton: Experiments on Timber.-Plate VII.

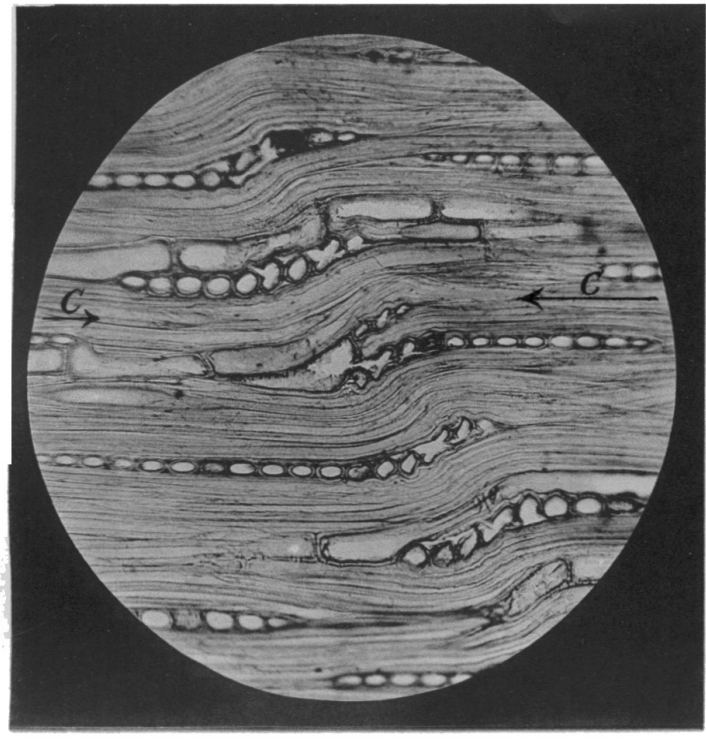

29

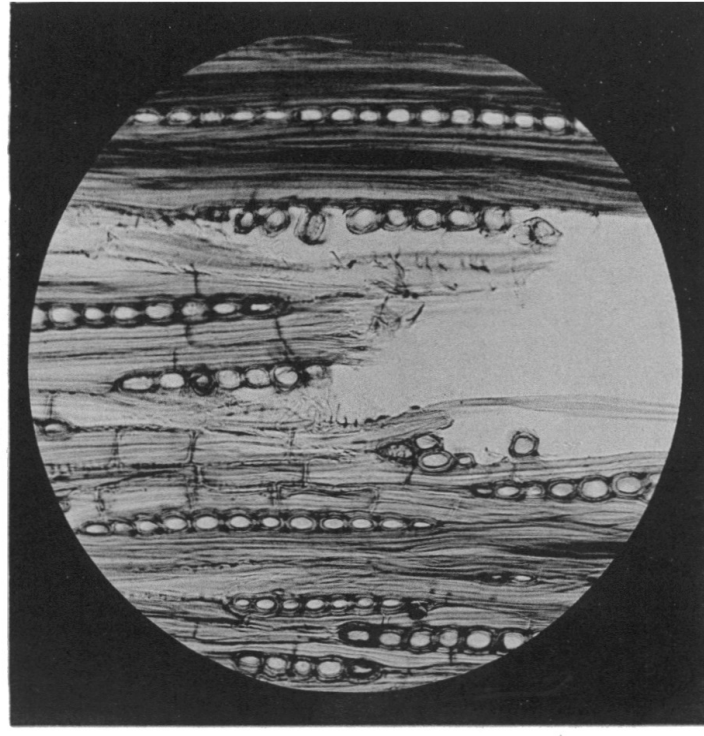

30

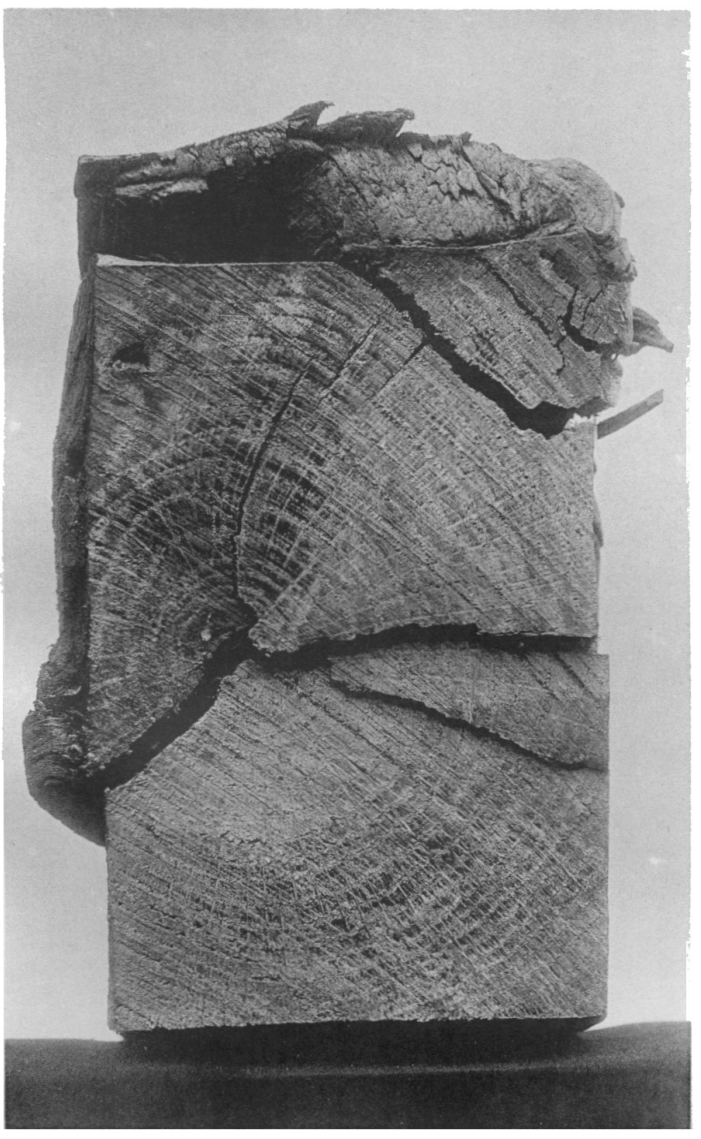

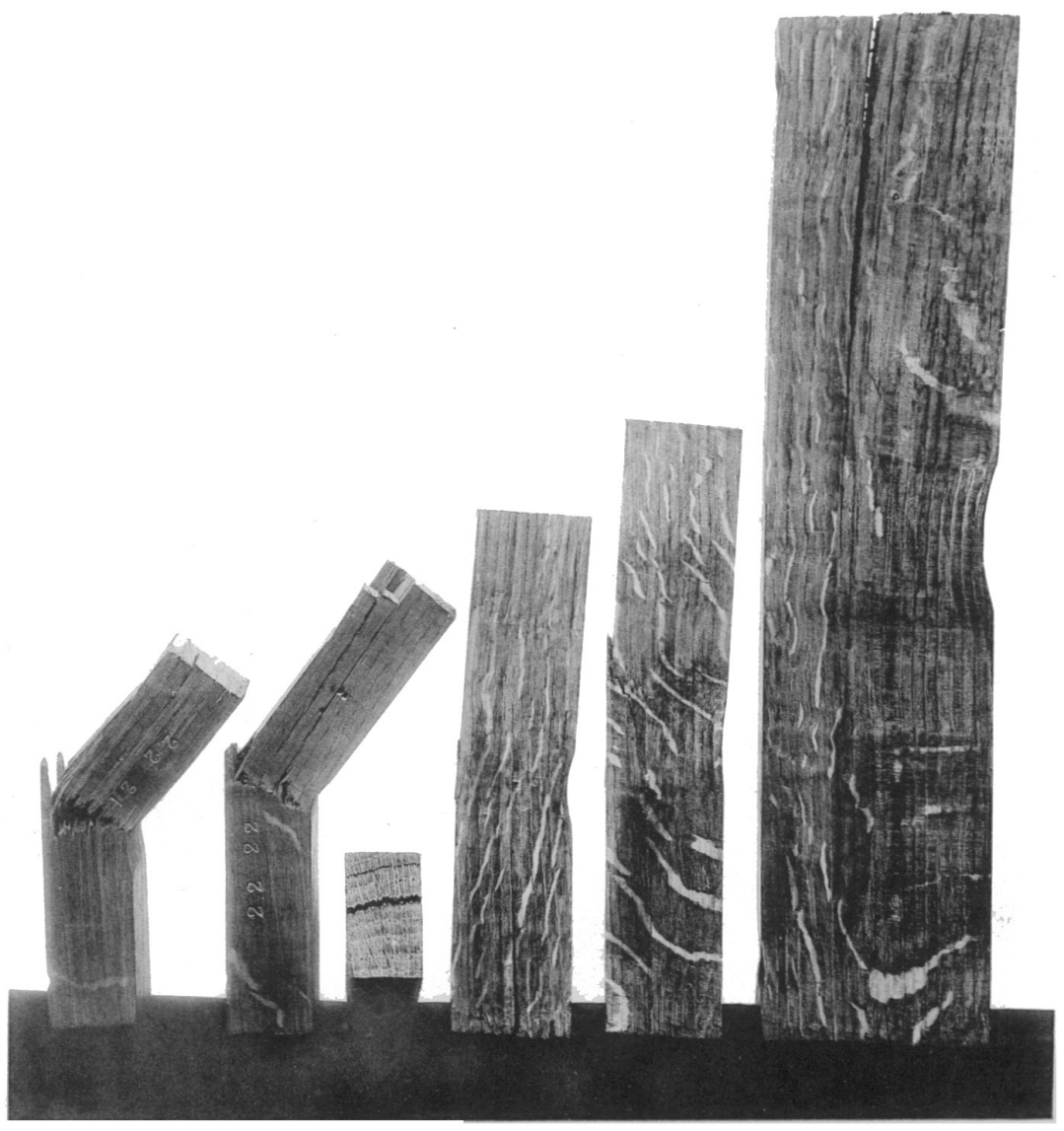


Fulton: Experiments on Trmber. -Plate ViII.

33
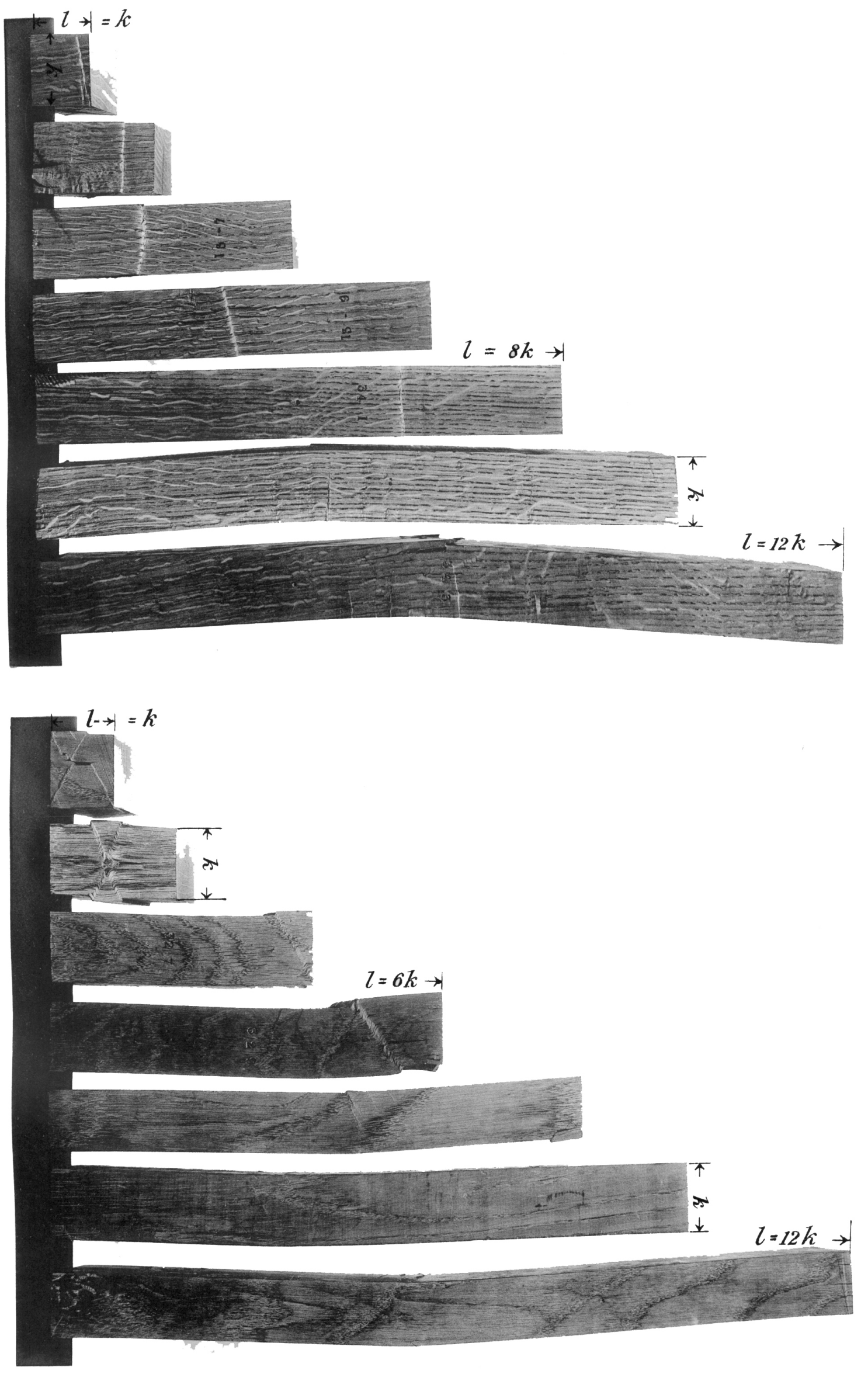